\title{
VULNERABILIDADE SOCIAL DOS ADOLESCENTES EM CONFLITO COM A LEI EM BOA VISTA - RORAIMA
}

\section{SOCIAL VULNERABILITY OF ADOLESCENTS IN CONFLICT WITH THE LAW IN BOA VISTA - RORAIMA}

\author{
Maria Clélia Lustosa Costa ${ }^{1}$ \\ Janaine Voltolini de Oliveira ${ }^{2}$
}

\section{Resumo}

O artigo em tela, de abordagem mista e natureza explicativa, elaborado por meio de procedimentos de pesquisa bibliográfica e documental a partir de 550 Procedimentos Apuratórios de Ato Infracional - PAAI, registrados entre os anos de 2006 a 2016 na 1a Vara da Infância e da Juventude da Comarca de Boa Vista, do Tribunal de Justiça do estado de Roraima 1 a VIJ/TJRR, se propõe a analisar a situação de vulnerabilidade social dos adolescentes em conflito com a lei residentes na área urbana da capital de Roraima a partir do exame de indicadores socioeconômicos extraídos destes processos judiciais. Constatou-se que, os maiores índices de criminalidade violenta concentram-se nos grupos mais vulneráveis socialmente e que o meio geográfico e cultural, ao qual estão inseridos, influencia diretamente na formação da identidade dos adolescentes e jovens e no ingresso à prática do ato infracional.

Palavras-chave: Adolescente; Ato Infracional; Conflito com a Lei; Violência Urbana; Vulnerabilidade Social

\begin{abstract}
The on-screen article, with a mixed approach and an explanatory nature, elaborated by means of bibliographic and documentary research procedures, based on 550 Procedures of an Infraction, from 2006 to 2016 at the 1st Infancy and Youth Court of the Comarca de Boa Vista, of the Court of Justice of the State of Roraima - 1st VIJ / TJRR, proposes to analyze the social vulnerability situation of adolescents in conflict with the law residing in the urban area of the capital of Roraima from the examination of indicators socioeconomic variables extracted from these judicial processes. It was found that the highest rates of violent crime are concentrated in the most socially vulnerable groups and that the geographic and cultural environment to which they are inserted directly influences the formation of the identity of adolescents and young people and the entry into the practice of the infraction.
\end{abstract}

Keywords: Adolescent; Infractionary Act; Conflict with the Law; Urban Violence; Social Vulnerability

\footnotetext{
1 Doutora pela Université Sorbonne Nouvelle - Paris III. Professora Associada do Departamento de Geografia da Universidade Federal do Ceará. Coordenadora do núcleo Fortaleza da Rede Observatório das Metrópoles: território, coesão social e governança democrática (INCT). E-mail: clelialustosa@gmail.com

2 Doutoranda em Geografia pelo Programa de Pós-Graduação em Geografia da Universidade Federal do Ceará (UFC). Professora do curso de Serviço Social na Universidade Estadual de Roraima (UERR). E-mail: jjanaine.voltolini@gmail.com
} 


\section{INTRODUÇÃO}

A violência urbana e a criminalidade juvenil são temas de grande relevância e com alto grau de complexidade. Por este motivo, tem ganhado corpo nas pesquisas acadêmicas das mais diversas áreas de conhecimento, especialmente das ciências humanas e sociais e, em muitos casos, entrelaçados com os temas da desigualdade social e da vulnerabilidade social.

Neste sentido, o artigo em epígrafe, intitulado "Vulnerabilidade social dos adolescentes em conflito com a lei em Boa Vista - Roraima", fundamenta-se na premissa de que é a vulnerabilidade social gerada e mantida pela profunda desigualdade social brasileira, a principal responsável por impulsionar os adolescentes para o conflito com a lei.

Isto posto, para alcançar o objetivo deste estudo, qual seja, analisar a situação de vulnerabilidade social dos adolescentes em conflito com a lei, residentes na área urbana da capital de Roraima, realizou-se pesquisa explicativa, com a combinação dos métodos quantitativo e qualitativo, elaborada por meio de procedimentos de pesquisa bibliográfica e documental a partir de 550 Procedimentos Apuratórios de Ato Infracional da 1a Vara da Infância e da Juventude do Tribunal de Justiça de Roraima, eleitos de forma aleatória, separados de acordo com a natureza dos conflitos, excluídos aqueles que não envolviam violência ou grave ameaça, ou seja, foram considerados para o estudo, processos judiciais que envolviam, segundo tipologia do Código Penal Brasileiro, os crimes contra o patrimônio - roubo ou tentativa de roubo, contra a dignidade - estupro, tentativa de estupro e contra a vida - homicídio e tentativa de homicídio.

A Comarca de Boa Vista compreende os municípios Cantá e Boa Vista, contudo, somente processos da capital foram considerados, já que o quantitativo é incomparavelmente maior e também porque o interesse se baseia na criminalidade em área urbana e, a maioria dos casos identificados no município do Cantá ocorreu na área rural, devido ao fato de sua população residente no campo (11.521 habitantes), segundo o Censo Demográfico 2010 (IBGE, 2010) superar a população da área urbana (2.257 habitantes).

Outro critério utilizado foi considerar apenas processos que continham a representação contra apenas um adolescente, ou seja, aqueles processos em que os adolescentes cometeram atos infracionais em comunhão de ações e desígnios com outro/outros adolescentes ou um ou mais adultos, foram descartados por se considerar que, individualmente analisados, têm-se maior clareza no levantamento das informações, pois tratam apenas das especificidades de um único representado. 
O juiz titular da 1a Vara da Infância e da Juventude concedeu autorização para manipulação os autos e coleta das informações requeridas, resguardados o sigilo dos nomes dos adolescentes e outras informações que pudessem os identificar. Três estagiários do 7o semestre do curso de Bacharelado em Serviço Social da Universidade Estadual de Roraima - UERR auxiliaram na coleta dos dados.

Os resultados extraídos corroboram a hipótese inicial que associa os adolescentes em conflito com a lei em Boa Vista à situação de vulnerabilidade social, já que apresentam um perfil de baixa escolaridade e pouco ou nenhum acesso à profissionalização (assim como seus pais ou responsáveis), início precoce de atividades laborais e em condições insalubres ou periculosas, baixa renda familiar, residência em áreas periféricas da cidade, uso e/ou abuso de substâncias psicoativas, entre outros, que expressam o urgente e necessário aprofundamento do tema em questão.

\section{ADOLESCÊNCIA E JUVENTUDE EM BOA VISTA - RORAIMA}

Segundo dados do Censo Demográfico do IBGE (2010), dos 284.313 habitantes de Boa Vista, 143.512 (50,5\%) são do sexo feminino e 140.801 (49,5\%) do sexo masculino. Destes, 119.194 (41,9\%) são adolescentes e jovens entre 10 a 29 anos, sendo 58.658 (49,2\%) do sexo masculino e 60.535 (50,8\%) do sexo feminino.

Embora o Estatuto da Criança e do Adolescente circunscreva a fase da adolescência entre os 12 e 18 anos incompletos e o Estatuto da Juventude defina a fase da juventude pela faixa etária que vai dos 15 aos 29 anos, para algumas políticas públicas, como a saúde, as fases sofrem descompasso. Segundo Brasil (2007), para a Organização Mundial de Saúde - OMS, a adolescência inicia e termina na segunda década de vida (10 a 19 anos de idade) e a juventude corresponde à idade dos 15 aos 24 anos.

Isto ocorre, porque:

A adoção do critério cronológico objetiva a identificação de requisitos que orientem a identificação epidemiológica, as estratégias de elaboração de políticas de desenvolvimento coletivo e as programações de serviços sociais e de saúde pública, porém, ignora as características individuais. Portanto, é importante ressaltar que critérios biológicos, psicológicos e sociais também devem ser considerados na abordagem conceitual da adolescência e da juventude (BRASIL, 2007, p. 7-8).

Em se tratando de adolescência, Brasil (2007, p. 8) estabelece a diferenciação entre esta e a puberdade, já que "na cultura ocidental contemporânea, existe o consenso de que os primeiros indícios da maturação sexual, introduzidos pela puberdade, marcam, concretamente, 
o início da adolescência". Na verdade, estabelece que adolescência "envolve um amplo processo de desenvolvimento biopsicossocial" (BRASIL, 2007, p. 8), sendo a puberdade uma parte dela, que se caracteriza mais por mudanças vinculadas à maturação corporal e aspectos hormonais; a adolescência significa, para além da puberdade, um fenômeno caracterizado por influencias socioculturais, que vão se concretizando por meio de reformulações constantes de caráter social, sexual e de gênero, ideológica e vocacional e, neste sentido, não se trata de uma única noção de adolescência, mas sim, de diferentes experiências e adolescências (BRASIL, 2007).

Ao tratar das vulnerabilidades e potencialidades desta fase, Brasil (2007, p. 8) destaca que a adolescência e a juventude merecem atenção do poder público por estar geralmente associadas às noções de "crise, desordem, irresponsabilidade, um problema social a ser resolvido" e, no caso da saúde, com enfoque de risco voltado às doenças sexualmente transmissíveis, uso de drogas lícitas e ilícitas, gravidez não planejada e morbimortalidade por acidentes e violências.

Por definição, "vulnerabilidade significa a capacidade do indivíduo ou do grupo social de decidir sobre sua situação de risco, estando diretamente associada a fatores individuais, familiares, culturais, sociais, políticos, econômicos e biológicos" (BRASIL, 2007, p. 9), ou seja, "a vulnerabilidade é uma noção multidimensional, à medida que afeta indivíduos, grupos e comunidade em planos distintos de seu bem-estar, de diferentes formas de intensidade (COSTA, 2009, p. 145).

A partir da criação do índice de desenvolvimento juvenil municipal - IDJM, Silveira (2009) calculou a vulnerabilidade social dos jovens do município de Boa Vista-RR tomando por base a análise das condições socioeconômicas e das dimensões de escolaridade dos jovens e de seus pais, saúde e renda. Foram pesquisados 386 jovens de 15 a 24 anos, com um nível de 95\% de confiança na pesquisa, ou seja, $5 \%$ de margem de erro.

Em relação à saúde, Silveira (2009, p. 12) afirma que o acesso dos jovens é restrito, pois muitos são privados de serviços essenciais "e os problemas se agravam, nem todos tem assegurado a cobertura de saúde, a nutrição, as instalações sanitárias ou a água potável".

A autora classifica como preocupante a condição juvenil em Boa Vista, pois o contexto socioeconômico reduz a expectativa de vida dos jovens. Para ela, o problema não está no acesso à escolarização, mas "a distorção idade-série, a permanência do aluno na escola e a qualidade do ensino, dificultam o processo de formação desses indivíduos, deixando-os expostos a alta vulnerabilidade" (SILVEIRA, 2009, p. 52). 
Figura 1 - Comparativo do Índice de Desenvolvimento Juvenil do Brasil, da Região Norte, do estado de Roraima e no município de Boa Vista - 2005

\begin{tabular}{l|c|c|c|c}
\hline & Educação & Saúde & Renda & IDJ \\
\hline Brasil & 0,632 & 0,626 & 0,348 & $\mathbf{0 , 5 3 5}$ \\
\hline Região Norte & 0,538 & 0,600 & 0,248 & $\mathbf{0 , 4 6 2}$ \\
\hline Roraima & 0,622 & 0,670 & 0,287 & $\mathbf{0 , 5 2 6}$ \\
\hline Boa Vista & 0,685 & 0,228 & 0,287 & $\mathbf{0 , 4 0 0}$ \\
\hline
\end{tabular}

Fonte: SILVEIRA (2009, p. 63) a partir dos dados da pesquisa e de WAISELFISZ (2007, p. 137).

Em sua pesquisa, destaca, entre outras coisas, que somente $22,2 \%$ dos jovens de Boa Vista chegam a concluir no máximo o Ensino Fundamental, 56,7\% cursam ou concluem o Ensino médio e 20,7\% chegam a cursar ou concluir o Ensino Superior, 4,1\% são analfabetos ou analfabetos funcionais, $36 \%$ estão fora da escola, $27 \%$ só trabalham e $9 \%$ não estudam nem trabalham. Revela que estes jovens têm mais anos de estudo que seus pais e que, por possuírem baixa escolaridade, grande parte dos responsáveis não consegue manter seus filhos estudando; estes, por sua vez, são levados a ingressar precocemente no mercado de trabalho, muitos para complementar o sustento do lar.

A pesquisa elucida ainda que $28 \%$ das famílias recebem até um salário-mínimo e 64,5\% recebem até três salários-mínimos (SILVEIRA, 2009), ratificando, em parte, o que havia sido diagnosticado pela gestão pública municipal em 2005.

A Secretaria Municipal de Gestão Participativa (SEMGEP) identificou parte da problemática que os jovens pobres enfrentam. No ano de 2005, foram pesquisados 58.803 jovens de 15 a 24 anos em quarenta e três bairros da cidade. Os dados levantados são preocupantes. Em relação a renda, os dados mostram que $74,2 \%$ tem empregos casuais e instáveis ou estão sem trabalhar. Na área educacional, somente $59,8 \%$ dos jovens frequentam a escola. Entre os jovens que estudam 4,0\% chegam ao Ensino Superior e somente 0,7\% concluem seus cursos (SILVEIRA, 2009, p. 52).

Ainda no campo da educação, a pesquisa identificou um elevado número de jovens analfabetos, dado que seguido da distorção idade/ano de escolarização e dos indicadores de qualidade do ensino, revelam as "lacunas existentes no processo de inserção dos jovens no mundo do trabalho e desenvolvimento da cidadania" (SILVEIRA, 2009, p. 12), o que impacta diretamente na situação socioeconômica das famílias, já que estas pessoas convivem com a ausência de oportunidades de desenvolvimento. 
Em outra pesquisa, que estabelece o Índice de Vulnerabilidade Juvenil à Violência e Desigualdade Racial - IVJ, realizada pela Secretaria Nacional da Juventude e Ministério da Justiça, tomando por base o ano de 2012, o estado de Roraima figura em 5o lugar na escala de vulnerabilidade, cujo índice 0,497 é considerado alto. Destaque-se que, da região Norte, é o primeiro estado a aparecer na lista, antecedido por quatro estados da região Nordeste Alagoas, Paraíba, Pernambuco e Ceará.

Figura 2 - IVJ - Violência e Desigualdade Racial 2014 e Risco Relativo, ano base 2012

\begin{tabular}{|c|c|c|c|}
\hline Unidades da federação & $\begin{array}{l}\text { IVJ - Violênciae } \\
\text { Desigualdade Racial }\end{array}$ & Escala de vulnerabilidade & Risco relativo \\
\hline Alagoas & 0,608 & Muito ata & 8,748 \\
\hline Paraíba & 0,517 & Muito ata & 13,401 \\
\hline Pernambuco & 0,506 & Muito ata & 11,565 \\
\hline Ceará & 0,502 & Muito ata & 4,011 \\
\hline Roraima & 0,497 & Ata & 3,287 \\
\hline
\end{tabular}

Fonte: BRASIL (2015, p. 18). IVJ - Violência e Desigualdade Racial 2014, ano-base 2012; Fórum Brasileiro de Segurança Pública. Escala de vulnerabilidade: Até 0,300 - Baixa; mais de 0,300 a 0,370 - Média-baixa; Mais de 0,370 a 0,450 - Média; mais de 0,450 a 0,500 - Alta; mais de 0,500 - Muito alta.

Observe-se, na figura 3, que a alta vulnerabilidade do estado de Roraima se deve, principalmente, pelos indicadores de mortalidade por acidentes de trânsito $(0,783)$, frequência à escola e situação de emprego $(0,631)$ e pobreza $(0,586)$.

No que diz respeito ao município de Boa Vista, o IVJ, calculado a partir de metodologia que analisa mortalidade por homicídios, mortalidade por acidentes de trânsito, frequência à escola, emprego, pobreza e desigualdade apresentou melhora no ano de 2012 em relação ao ano de 2007. A capital, que em 2007 detinha alto IVJ e assentava-se na 50a posição $(0,460)$ entre os municípios com os piores índices de vulnerabilidade juvenil à violência, caiu, em 2012 para a 119ạ posição no ranking, que a classifica seu IVJ como médio $(0,411)$.

A capital apresentou índice 0,234 no indicador de mortalidade por homicídio, 0,517 em relação ao indicador de mortalidade por acidentes de trânsito e 0,510 no indicador de frequência à escola e situação de emprego. Entre os indicadores, o de pobreza se apresenta como o mais elevado - 0,672 e o de desigualdade o mais baixo -0,178. 
Figura 3 - IVJ - Violência e Desigualdade Racial 2014, ano base 2012

Fonte: BRASIL (2015, p. 19). IVJ - Violência e Desigualdade Racial 2014, ano-base 2012; Fórum Brasileiro de Segurança Pública.

De acordo com a Prefeitura de Boa Vista (2016, s/p.) existiam, em 2001, trinta e cinco gangues urbanas, "conhecidas pela prática de atos violentos, disputas territoriais e 
envolvimento com o tráfico de drogas. Conhecidas como "galeras", eram integradas por jovens, a maioria moradores de regiões de alta vulnerabilidade social". A partir deste dado, a prefeitura realizou "um amplo diagnóstico socieconômico, que abrangeu todo o município, os números da violência tornaram-se nomes, rostos, endereços e ganharam uma explicação: a situação de pobreza e indigência em que viviam cerca de 17 mil adolescentes" (PREFEITURA DE BOA VISTA, 2016, s/p.).

Com ações específicas e focalizadas nas regiões de atuação das galeras, como o projeto Esporte noite a dentro, a gestão municipal iniciou o contato com estes adolescentes, estabelecendo os primeiros passos para o mais importante e premiado ${ }^{3}$ projeto social de enfrentamento da violência juvenil até então desenvolvido na capital, o Crescer.

No início, eles chegaram a se esfaquear na minha frente. Em um determinado momento, me entregaram as armas. Pedi a um desses garotos para sentar na minha mesa e ouvir todos os problemas da cidade. Criamos com eles uma relação de respeito,algo que eles não tinham por ninguém", conta a Prefeita Teresa Surita, criadora do projeto junto ao gestor Moacir Collini (PREFEITURA DE BOA VISTA, 2016, s/p.).

Em 2004, para atender a demanda de jovens do projeto, foi criada a Escola Frei Arthur Agostini, que, com uma matriz curricular diferenciada, oferecia, além de aulas regulares, "oficinas de artes plásticas, moda, música, xadrez e cursos profissionalizantes. Além disso, uma cooperativa foi fundada para comercialização dos produtos criados pelos alunos, que dividiam a renda" (PREFEITURA DE BOA VISTA, 2016, s/p.). O trabalho da instituição, que chegou a atender cerca de 900 pessoas em 2006, encerrou-se na administração seguinte, deixando como legado a redução das galeras - de trinta e cinco para apenas cinco, de acordo com o "Instituto Sangari, baseado em dados do Ministério da Justiça, e a violência juvenil teve redução de $72 \%$ entre 2001 e 2007, de acordo com informações da Polícia Militar de Roraima" (PREFEITURA DE BOA VISTA, 2016, s/p.).

A partir daí os números da violência urbana juvenil voltaram a subir, conforme se observa na figura 4, embora se observe uma leve queda no ano de 2010.

Faz-se necessário esclarecer que, em se tratando de dados estatísticos de atos infracionais cometidos por adolescentes em Boa Vista, foram encontradas algumas lacunas: subnotificação de casos, irregularidades no preenchimento das informações, dados que não se comunicam entre as instituições de segurança pública - delegacias e secretarias fazem seu

\footnotetext{
${ }^{3}$ O projeto Crescer recebeu diversos prêmios pela sua excelência na área social, como o da Fundação Getúlio Vargas e da Petrobras e foi reconhecido pelo Ministério da Justiça como uma das iniciativas mais avançadas no enfrentamento à violência juvenil.
} 
próprio sistema de armazenamento ou banco de dados e estes não são avaliados na eficiência e não existe cruzamento de informações. Ressalta-se ainda que, apesar de solicitados, os dados das delegacias de polícia civil que registram atos infracionais não foram disponibilizados.

Figura 4- Taxa de crimes ${ }^{4}$ com infrator menor de 18 anos de idade em Roraima $2007 / 2010$

\begin{tabular}{|c|c|}
\hline Ano & Crimes com infrator menor de 18 anos (por 100.000 habitantes) \\
\hline 2007 & 384,6 \\
\hline 2008 & 487,4 \\
\hline 2009 & 582,9 \\
\hline 2010 & 541,4 \\
\hline
\end{tabular}

A partir de 2014, com o retorno da prefeita Teresa Surita à administração municipal, o projeto teve nova retomada, agora com o desafio de enfrentamento do crack. Atualmente, o projeto atende cerca de 500 jovens, que participam de "oficinas de marcenaria, luteria, serralheria, metalurgia, moda, serigrafia, educação para o trânsito e sinalização, artesanato, música, dança, cinema e meio ambiente" (PREFEITURA DE BOA VISTA, 2016, s/p.), sendo que a ampliação do número de adolescentes participantes está em consonância com a implementação de novas oficinas, como "cozinha regional e panificação, hip hop, informática, teatro e biojoias. Há, ainda, atividades esportivas como futebol de campo, vôlei e gincanas" (PREFEITURA DE BOA VISTA, 2016, s/p.).

Importa ressaltar que, concomitante ao projeto Crescer, a Prefeitura de Boa Vista executa ainda outros projetos voltados à infância, adolescência e juventude e jovens em situação de pobreza e vulnerabilidade social, já que, segundo Lima (2001), as vulnerabilidades vividas na infância refletem nos demais estágios de vida.

Isto posto, requer de todos a compreensão de que, embora Boa Vista apresente, em relação aos demais municípios de Roraima, um melhor Índice de Desenvolvimento Humano Municipal - IDHM e menores Índices de Vulnerabilidade Social - IVS, o que gera um maior índice de prosperidade social, são as desigualdades intraurbanas que promovem novos padrões de segregação socioespacial, refletindo em formas espaciais desiguais e na alteração das relações sociais, o que promove profundas disparidades no acesso a produtos e serviços públicos e implica diretamente na noção de direitos (ou violação deste) e no exercício da cidadania.

\footnotetext{
${ }^{4}$ Terminologia utilizada pela fonte da pesquisa.
} 


\section{ADOLESCENTES EM CONFLITO COM A LEI EM BOA VISTA - RORAIMA}

Na figura 5 é possível observar que entre os anos 2005 a 2008 houve um aumento de mais de $277 \%$ de Procedimentos Apuratórios de Ato Infracional - PAAI em relação ao primeiro período (2001 a 2004) e uma posterior queda nos anos seguintes, com uma inversão em relação aos Boletins de Ocorrência Circunstanciados - BOC.

Outro fato a ser anunciado é a redução de feitos de natureza infracional na Comarca de Boa Vista no último período. Entre 2001 a 2004, a Comarca registrou, entre PAAI e BOC, 1.357 feitos; entre 2005 a 2008 foram registrados 3.762 feitos e 4.158 em relação aos anos 2009 a 2012; os números sofrem queda de quase 22\%, chegando a 3.222 feitos entre 2013 e 2016.

Figura 5 - Total de feitos por classe - Comarca de Boa Vista - RR, infracional 1a VIJ/TJRR (2001-2016)

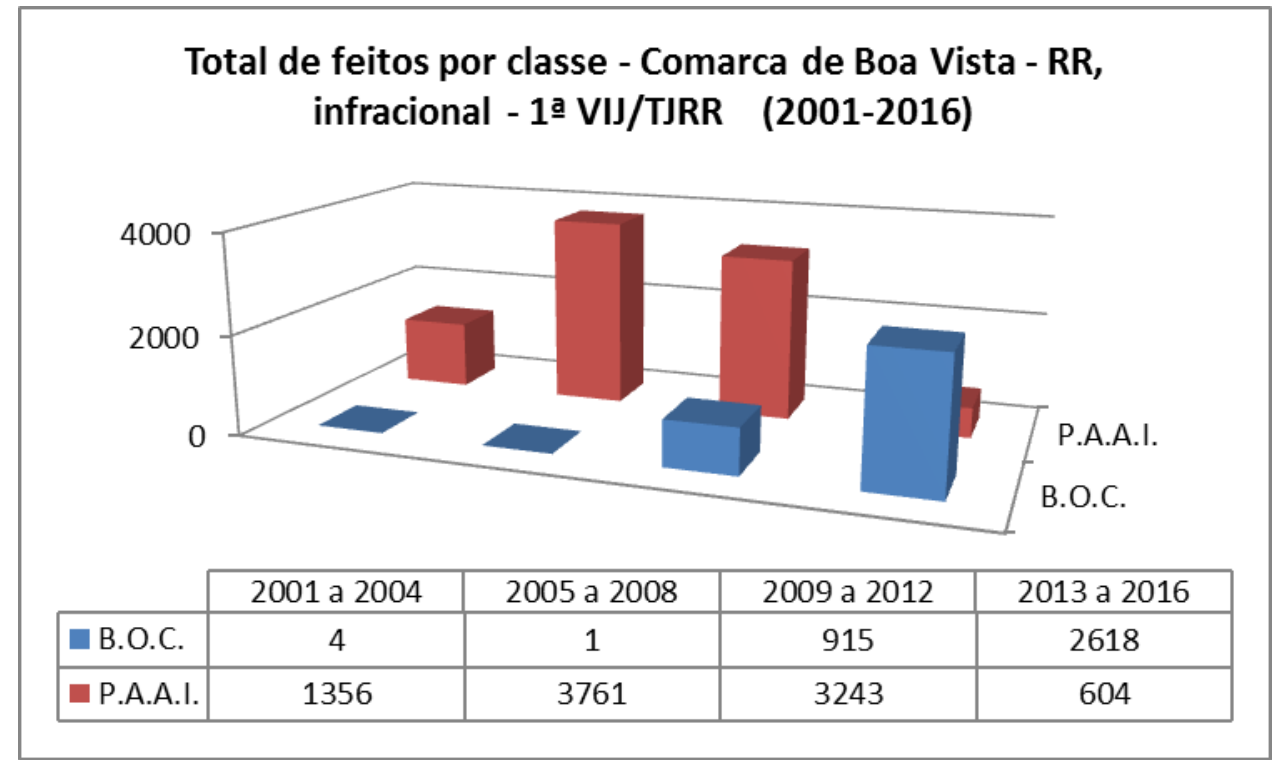

Fonte: SISCOM - Sistema de Informação das Comarcas. Elaboração própria.

Para facilitar a manipulação dos processos e a posterior tabulação das informações referentes aos indicadores socioeconômicos dos adolescentes em conflito com a lei em Boa Vista - Roraima, foi criado um banco de dados que pudesse ser alimentado por eixos, subdividindo por três áreas de interesse: 1 ) indicadores socioeconômicos do adolescente em conflito com a lei - idade, estado civil, cor/raça, sexo, naturalidade, escolaridade, ocupação, bairro de residência e responsável; 2) indicadores socioeconômicos dos responsáveis pelo adolescente em conflito com a lei - naturalidade, escolaridade, ocupação e renda; 3) informações sobre o ato infracional e uso de substâncias psicoativas pelo adolescente em 
conflito com a lei - natureza do ato, local de cometimento do ato infracional, antecedentes/reincidência, uso de drogas, tipo de droga consumida/experimentada.

Já durante a coleta de dados percebeu-se que os resultados da pesquisa relacionados a alguns indicadores poderiam ter sido comprometidos, o que foi confirmado no decurso da tabulação. Isto porque, as informações que se buscava poderiam estar no Boletim de Ocorrência Circunstanciado - BOC ou Registro de Ocorrência Policial - ROP, da Polícia Militar do Estado de Roraima, na representação do Ministério Público do Estado de Roraima - MPE, nos depoimentos prestados pelos adolescentes nas Delegacias de Polícia Civil (a pesquisa teve um recorte temporal de 10 anos e, portanto, foram várias as delegacias - 5o Distrito Policial, Delegacia de Defesa da Infância e da Juventude - DDIJ e etc), nos laudos elaborados por assistente social, psicólogo e pedagogo da equipe interprofissional - área infracional (nem todos os adolescentes passaram pela equipe), na Ficha Criminal (ou ficha de antecedentes do menor) ou na Ficha Civil da Secretaria de Segurança Pública do estado de Roraima. Dificilmente, pela própria natureza das atividades, havia informações das quais se procurava nos documentos da Defensoria Pública Estadual - DPE ou nos despachos do juiz.

No caso das informações relacionadas à situação socioeconômica do adolescente em conflito com a lei, percebeu-se que os indicadores cor/raça, cuja informação estaria na Ficha civil, grande parte das vezes, ou não estavam ou não havia a própria ficha nos autos e o dado, considerado de autopercepção, não consta em nenhum outro documento.

O mesmo aconteceu quando da busca de informações sobre antecedentes ou reincidência de ato infracional. Estas informações deveriam estar contidas na Ficha Criminal do adolescente (ou ficha de antecedentes), contudo, em alguns processos não havia a ficha.

Desta forma, para evitar suposições ou mesmo legitimar informações que possam ser facilmente contestadas por ausência de dados ou falta de qualidade na referência, optou-se por não expor os resultados destes indicadores, embora façamos uma discussão dos mesmos com base na revisão bibliográfica.

Conforme se observa na Figura 6, no que diz respeito à idade dos adolescentes em conflito com a lei em Boa Vista, têm-se que 78,72\% cometem ato infracional entre os 15 e 17 anos, ou seja, a fase de transição entre a adolescência e a juventude. Na pesquisa, 16 (2,91\%) dos adolescentes cometeram atos infracionais aos 12 anos, 29 (5,27\%) aos 13 anos, 72 (13,1\%) aos 14 anos, 131 (23,82\%) aos 15 anos, 162 (29,45\%) aos 16 anos e 140 (25,45\%) aos 17 anos. 
Figura 6 - Idade dos adolescentes em conflito com a lei em Boa Vista - RR

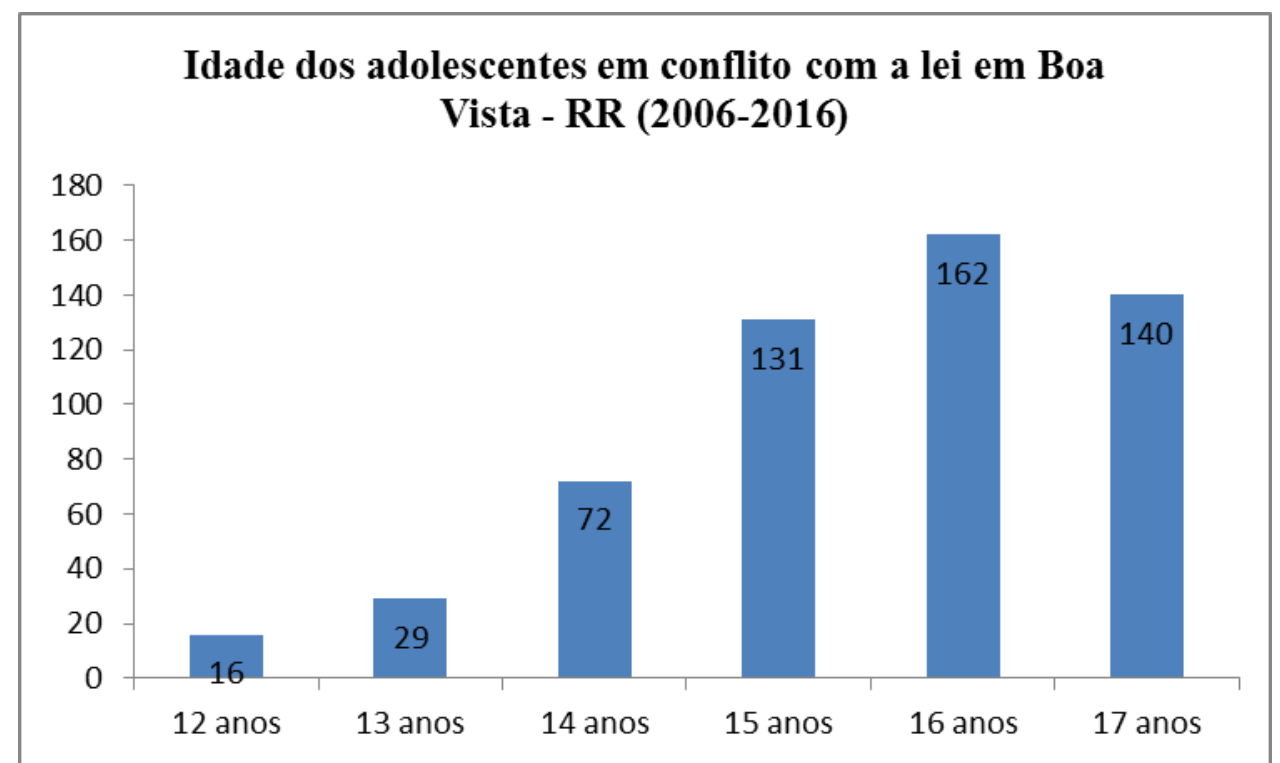

Fonte: Pesquisa realizada em processos judiciais de ato infracional na 1a Vara da Infância e da Juventude da Comarca de Boa Vista - Tribunal de Justiça do Estado de Roraima. Elaboração própria.

Nota-se que os primeiros anos da adolescência - 12 aos 14 anos são menos representativos para a análise do ato infracional do que os últimos três anos, provavelmente porque, seja ainda a fase em que a família consegue exercer maior poder sobre os filhos, tanto no sentido da imposição de regras, limites e transferência de valores, quanto na obrigatoriedade de frequentar instituição de ensino, o que veremos mais a frente.

O Conselho Nacional de Justiça - CNJ, em pesquisa sobre o panorama nacional da execução das medidas socioeducativas de internação, apresentou a faixa etária das crianças ou adolescentes quando do primeiro ato infracional, por região. Nela, todas as regiões confirmam a ocorrência do primeiro ato infracional entre 15 a 17 anos (47,5\%), embora somente a região Nordeste tenha apresentado maioria absoluta dos casos nesta faixa etária (54\%), conforme se observa no gráfico abaixo. 
Figura 7 - Faixa etária das crianças ou adolescentes quando do primeiro ato infracional por região geográfica

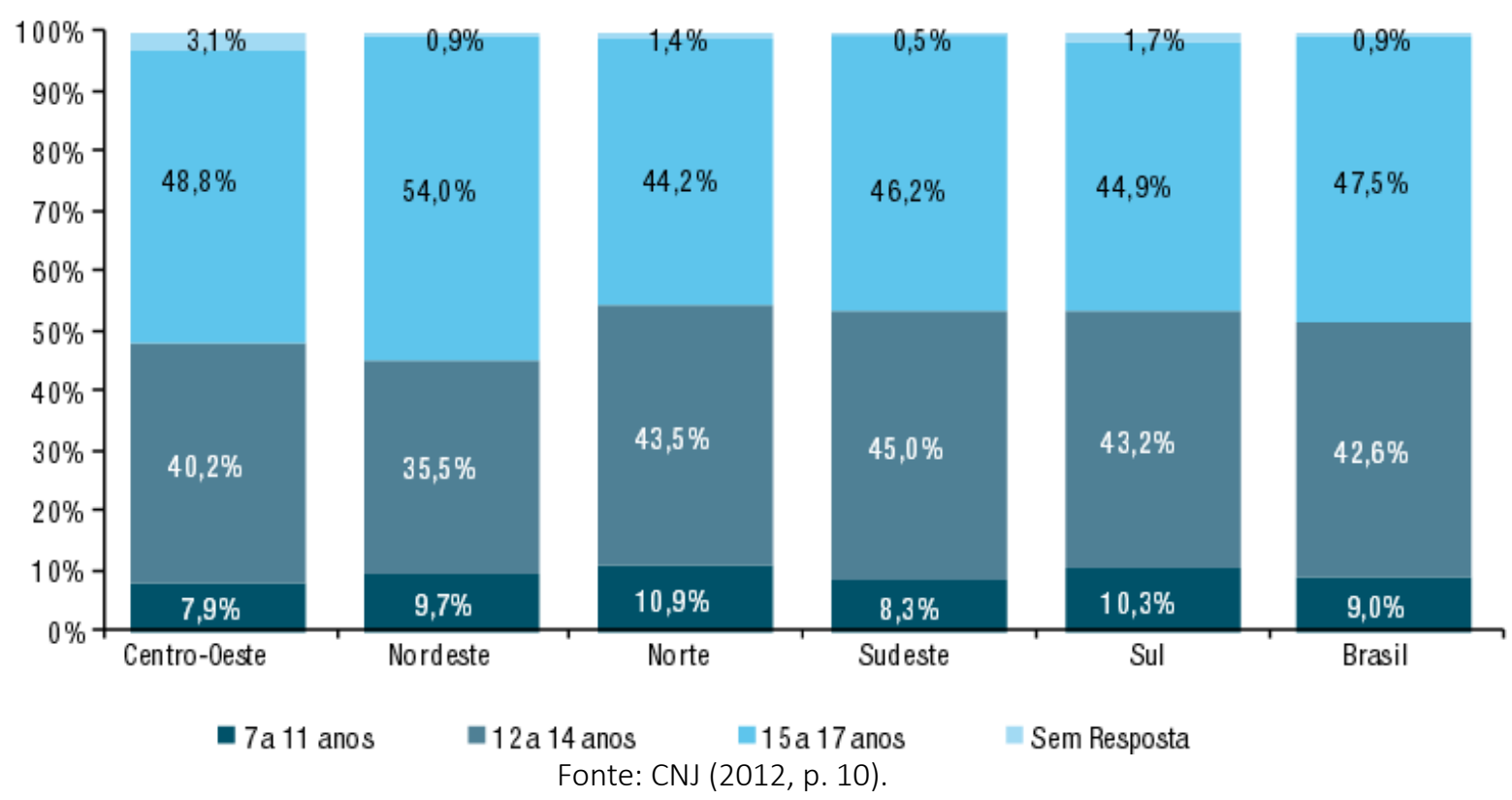

Em relação ao indicador sexo, 523 (95,09\%) adolescentes foram identificados como sendo do sexo masculino e 27 (4,91\%), como sendo do sexo feminino - Figura 8.

Figura 8 - Adolescentes em conflito com a lei em Boa Vista/RR por sexo (20062016)

\section{Adolescentes em conflito com lei em Boa Vista - RR por sexo (2006-2016)}

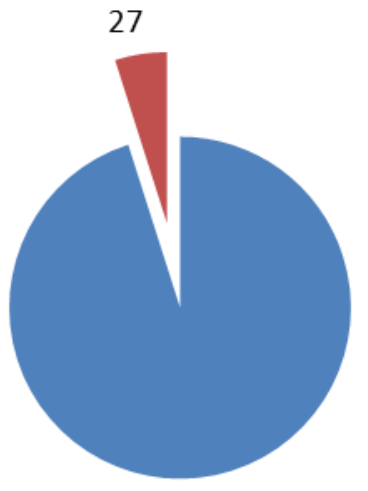

Masculino

- Feminino

Fonte: Pesquisa realizada em processos judiciais de ato infracional na 1a Vara da Infância e da Juventude da Comarca de Boa Vista - Tribunal de Justiça do Estado de Roraima. Elaboração própria. 
Esta disparidade numérica encontra apoio nas pesquisas voltadas ao tema da violência e da criminalidade, seja adolescente, juvenil ou adulto. Segundo Bastos (2009), a taxa de delinquência feminina no Brasil, na década de 1950 era de 2\% em relação à masculina. No ano de 2000, passou a representar 3,5\% de toda a população carcerária brasileira.

Analisando as informações do Sistema de Informações Penitenciárias (InfoPen), da Secretaria de Segurança Pública, demonstrados nas figuras 9, 10 e 11, tem-se que a população absoluta de mulheres encarceradas no sistema penitenciário feminino brasileiro aumentou 567\% entre os anos de 2000 a 2014.

De acordo com Murray (2001), dos mais de 100 mil presos condenados no Brasil, apenas $4 \%$ são mulheres. E de cada grupo de 100 dessas mulheres, 60 estão envolvidas no tráfico de drogas. Elas são chamadas "mulas", que transportam as drogas e geralmente são levadas ao crime pelos parceiros ou companheiros.

Figura 9 - Evolução da população prisional por sistema - Brasil - 2000 a 2014

Fonte: BRASIL (2014, p. 8). 
Figura 10 - Evolução da população prisional segundo gênero - Brasil - 2000 a 2014

Fonte: BRASIL (2014, p. 10).

Figura 11 - Evolução da população de mulheres no sistema penitenciário Brasil - 2000 a 2014

Fonte: BRASIL (2014, p. 10).

No tocante à escolaridade os números são preocupantes, haja vista que apresentam uma importante defasagem idade/tempo de escolaridade entre os adolescentes pesquisados. Destes, $1(0,18 \%)$ se identificou como alfabetizado, 16 (2,91\%) informaram ter concluído o ensino fundamental, 55 (10\%) estudaram ou estavam estudando o 1으 ao 4o ano do ensino fundamental, enquanto que 250 (45,45\%) não haviam concluído o ensino fundamental do 5 o ao 9o anos. Sobre o ensino médio, 10 (1,82\%) haviam concluído e 93 (16,91\%) estavam cursando ou haviam se matriculado no 1 o aos 3 o anos. Apenas $1(0,18 \%)$ adolescente cursava o ensino superior e 124 (22,55\%) não informaram escolaridade. 
A pior e mais preocupante das informações é a de que, entre os 426 adolescentes que informaram alguma escolaridade, 381 (89,43\%) não estavam frequentando nenhuma escola, ou seja, os que estavam matriculados informaram estar evadidos ou não frequentando e os demais nem matriculados no ano corrente ao ato infracional estavam. Fato comum de observar é a evasão motivada por suspensões ou seguidas reprovações e ainda as expulsões de adolescentes a partir da tomada de conhecimento, pela escola, de que este está ou esteve envolvido com o sistema de justiça.

Este índice de defasagem escolar contribui sobremaneira para o fracasso dos adolescentes, seja ele escolar, profissional ou até mesmo pessoal. O fato de não frequentar estabelecimento de ensino, além de representar um não exercício de direito previsto na Constituição Federal de 1988 e no Estatuto da Criança e do Adolescente, representa ainda uma barreira no acesso a programas ou projetos sociais, cursos profissionalizantes ou projetos voltados ao primeiro emprego.

A ausência de escolarização reflete no trabalho infanto-juvenil, no aumento da criminalidade violenta, na exploração do trabalho, na baixa autoestima do adolescente e do jovem, no vocabulário, entre tantos outros elementos.

Figura 12 - Escolaridade dos adolescentes em conflito com a lei em Boa Vista RR. (2006-2016)

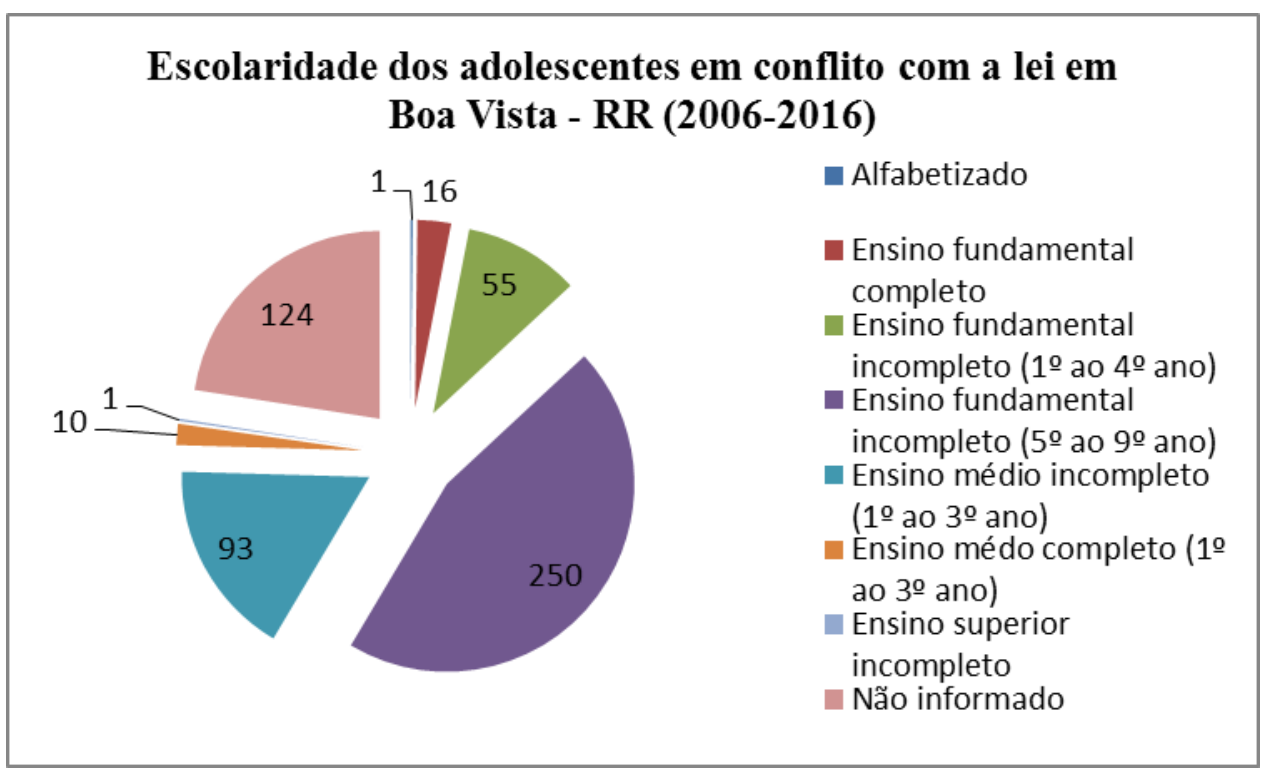

Fonte: Pesquisa realizada em processos judiciais de ato infracional na 1a Vara da Infância e da Juventude da Comarca de Boa Vista - Tribunal de Justiça do Estado de Roraima. Elaboração própria. 
Retomando a pesquisa do CNJ (2012), têm-se que os adolescentes em conflito com a lei interrompem seus estudos entre 8 e 16 anos. As regiões Norte e Nordeste são as que comportam adolescentes com menos anos de escolarização; nestas regiões eles param de estudar em média aos 13,7 anos, enquanto que na média nacional interrompem seus estudos aos 14 anos (Figura 13), ou seja, não chegam a concluir o ensino fundamental (Figura 14). É também nas regiões Norte e Nordeste que a frequência dos adolescentes à escola é menor: na região Norte, $58,7 \%$ deles não frequentam a escola todos os dias e na região Nordeste, $57,4 \%$ (Figura 15).

Figura 13 - Média de idade em que o adolescente interrompeu os estudos por região

\begin{tabular}{|cc|}
\hline Regiắo & Idade Média \\
\hline Centro-0este & 14,2 \\
\hline Nordeste & 13,7 \\
\hline Norte & 13,7 \\
\hline Sudeste & 14 \\
\hline Sul & 14,3 \\
\hline Total & $\mathbf{1 4}$ \\
\hline
\end{tabular}

Fonte: CNJ (2012, p. 14) 
Figura 14 - Última série escolar cursada pelo infrator por região
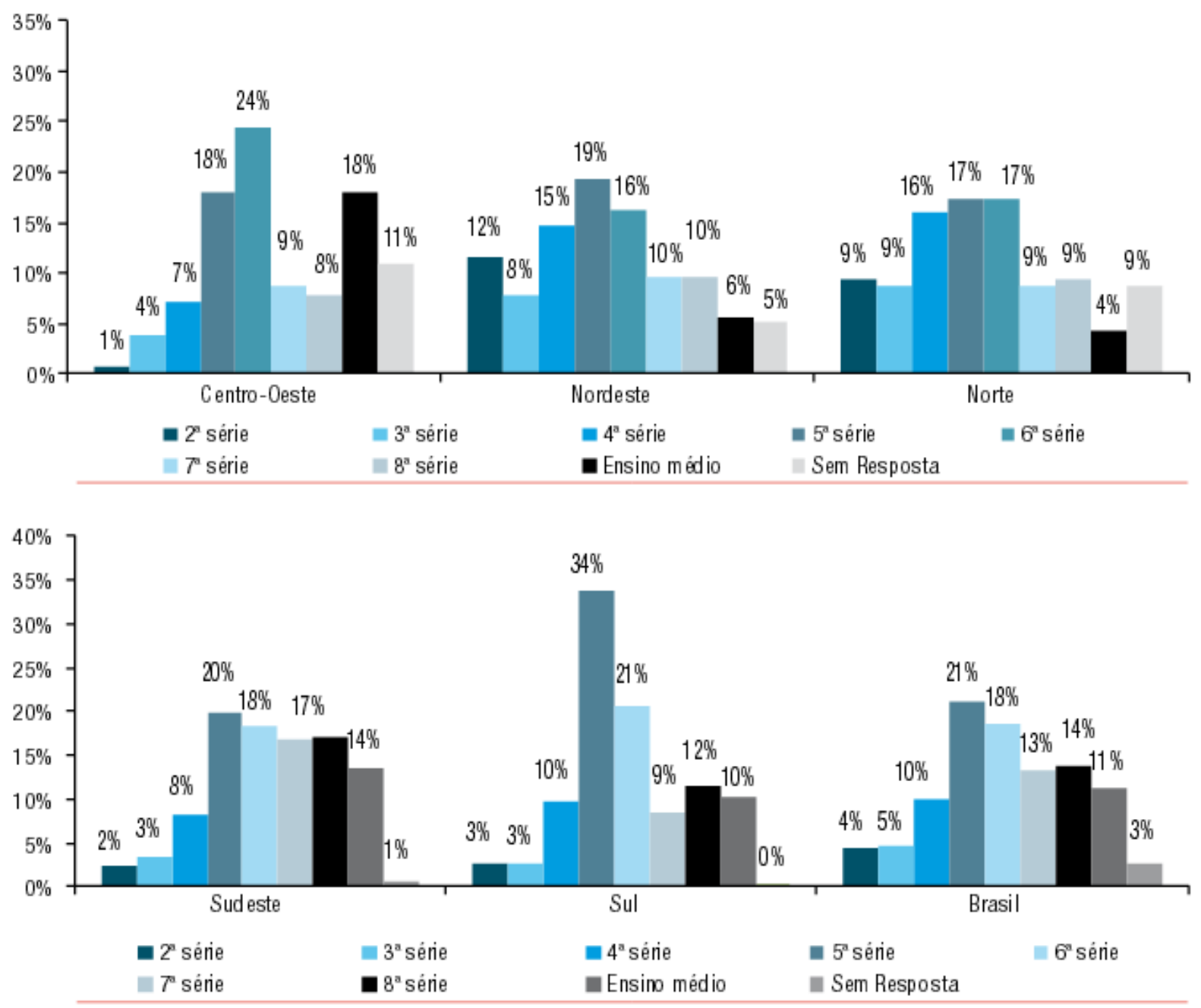

Fonte: CNJ (2012, p. 15)

Figura 15 - Frequência diária à escola dos adolescentes por região

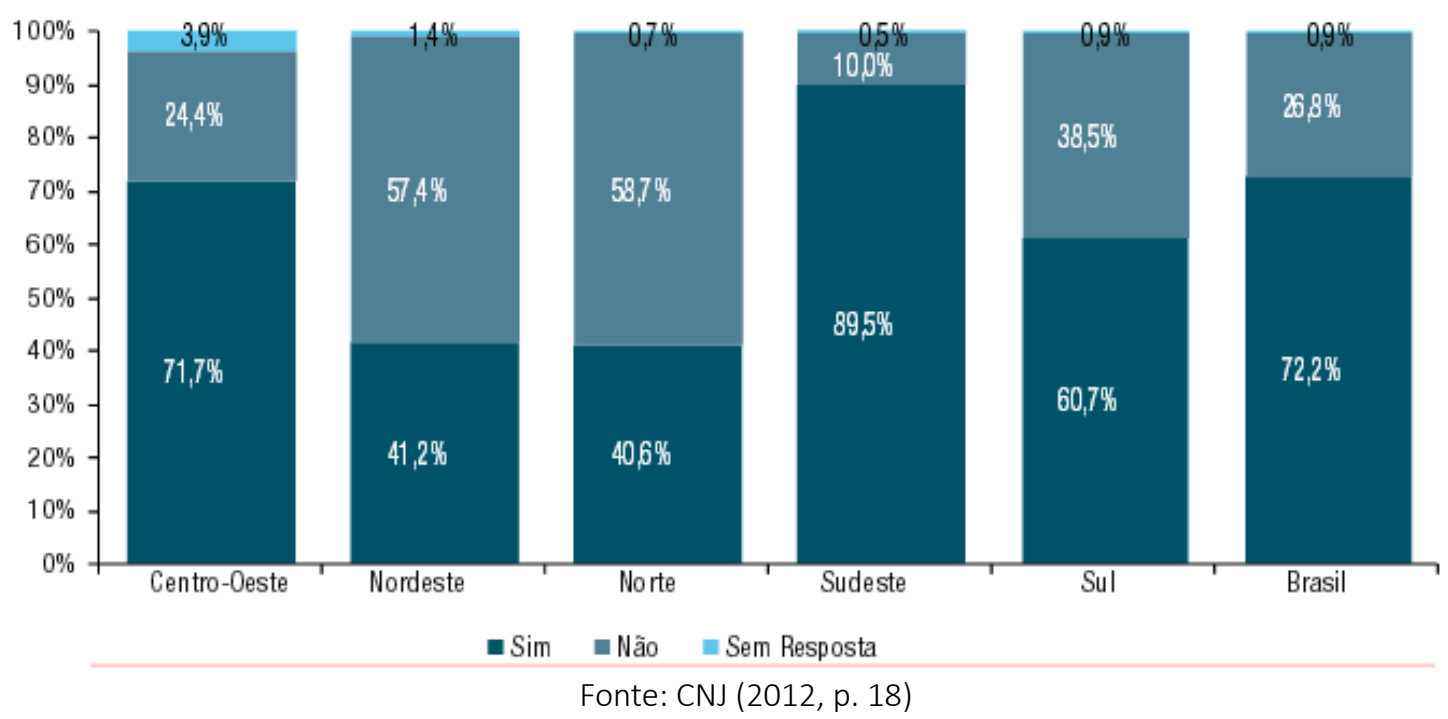

Revista de Direito da Cidade, vol. 10, no 1. ISSN 2317-7721 pp. 33-77 50 
Cerqueira (2016, p. 27), num estudo sobre o "papel crucial que um adequado processo educacional pode exercer para o desenvolvimento infanto-juvenil e para a prevenção aos crimes", destaca falhas do modelo educacional brasileiro, considerado por ele como limitado, burocrático e enciclopédico e que acaba por não motivar os alunos, enxergar suas especificidades e ideais e que, portanto, não cumpre sua função.

Para o autor, o objetivo da educação deve girar no "sentido de desenvolver capital humano, que faz aumentar a probabilidade de empregabilidade do indivíduo, bem como o seu salário real esperado no mercado de trabalho" (CERQUEIRA, 2016, p. 31). Como contrapartida, tem-se "o aumento do custo de oportunidade para cometer crimes" (CERQUEIRA, 2016, p. 31).

Segundo o autor, "o desinteresse ou a rebeldia do aluno é visto como uma "nãoconformidade", devendo a criança "desajustada" ser reprovada ou expulsa da escola (CERQUEIRA, 2016, p. 30), que "poderia ser a pedra fundamental transformadora para prevenir crimes no Brasil, termina não explorando determinados efeitos potenciais desejados, em face de um modelo educacional que não reconhece diferenças individuais e sociais" (CERQUEIRA, 2016, p. 30) e afasta principalmente indivíduos com "trajetórias e desvantagens distintas" (CERQUEIRA, 2016, p. 30).

Por sua vez, Correa (2008, p. 16), ao tratar do difícil acesso à educação na sociedade do conhecimento, ${ }^{5}$ questiona "como, então, a reprodução social e cultural no Brasil se realiza quando um grande número de jovens se encontra numa zona de risco ou de vulnerabilidade?", levantando um cenário em que a participação dos jovens na sociedade é limitado e cheio de desafios, tais como a globalização da economia, a sociedade do conhecimento e a cultura de massa.

[...] o processo de globalização originou transformações nas relações econômicas e sociais, que impactando o mundo todo, tiveram especial efeito na juventude. A globalização e universalização das comunicações, da publicidade, da TV a cabo, da internet e as crescentes trocas a partir da nova conectividade originaram novos ordenamentos e arranjos na vida cultural, social e laboral. Para a juventude, tem significado profundas mudanças nas formas de se relacionar com os outros, de aprender e de construir-se como parte da sociedade (WAISELFISZ, 2007, p. 12).

Isto porque, em determinado momento, a globalização favorece alguns países num setor específico como a indústria, por exemplo, desfavorece outros de economia mais vulnerável, caso dos países emergentes como o Brasil (FURTADO, 2001), o que implica

5 Sobre o assunto, consultar: COUTINHO, Clara.; LISBÔA, Eliana. Sociedade da informação, do conhecimento e da aprendizagem: desafios para a educação no século XXI. Revista de Educação, vol. XVIII, no 1, 2011, p. 5-22. Disponível em: http://revista.educ.ie.ulisboa.pt/arquivo/vol_XVIII_1/artigo1.pdf. Acesso em: 3 nov. 2017. 
diretamente no desemprego e num mercado de trabalho que não atende as demandas dos jovens por emprego, que impacta diretamente na educação profissional, no mercado informal e na precarização das formas de trabalho (CORREA, 2008).

Neste contexto, sugere ainda a inacessibilidade ao ensino superior para mais de $90 \%$ dos jovens brasileiros, sendo a formação e a formação continuada grandes desafios para a sociedade do conhecimento, que reforça o processo de individualização e exige cada vez mais qualificação atualização de competências (CORREA, 2008), problemas estes que, segundo Pochman (2004), deveriam ser atacados na ordem quantitativa, com o acesso dos jovens à educação escolar e na ordem qualitativa, com ensino de qualidade.

Beck (1990 apud CORREA, 2008, p. 18) "acentua o sucesso escolar para a obtenção de uma posição aceitável na sociedade de conhecimento, que exige cada vez mais um alto nível de educação que estimule a competição e a mobilidade social e geográfica", que, por sua vez, acabam também por estimular a concorrência e a individualização.

Além disso, a cultura de massa, recente no Brasil, influencia as relações inter e intrageracionais e transforma bens culturais em mercadorias, transformando os jovens em potenciais consumidores, especialmente de produtos de grande apelo comercial, como a indústria de produtos audiovisuais (CORREA, 2008, p. 19).

Os atuais jovens entre 15 e 24 anos nasceram numa sociedade em vias de democratização política e de globalização econômica e cultural. Trata-se de uma geração que não conheceu a censura militar e que cresceu vendo televisão e escutando músicas produzidas pela indústria fonográfica com venda de milhões de cópias de discos. Essa mesma geração se habitou com vitrines de shopping centers e fez desses centros um dos seus principais espaços de vivencia juvenil. Evidentemente, a indústria cultural tem um papel importante nas práticas culturais dos jovens. Os jovens se tornam também atores das mudanças culturais e sociais junto aos seus grupos de pertencimento. A cultura de massa permite igualmente entender melhor uma das características da juventude atual. Trata-se da consumação no sentido evocado pelo psicanalista Jurandir Freyre (2004) (CORREA, 2008, p. 19).

Os jovens brasileiros dividem-se em grupos de consumidores segundo seu poder aquisitivo, sendo a maioria deles com baixo poder de compra e, a partir das áreas de interesse (esportes, música, lazer, vestuário, tecnologias digitais etc.) definem seus objetos de desejo. Aquilo que parece supérfluo para um grupo, tem valor simbólico e monetário a outro (CORREA, 2008). 
Ocorre que "a distância entre o sonho de consumação e o poder de compra pode suscitar um aumento da criminalidade entre os jovens [...]. Eis aqui um dos problemas da individualização num quadro de socialização precária" (CORREA, 2008, p. 19). "Assim, o aumento da criminalidade não tem ligação direta com a pobreza, mas com a socialização precária e a inculcação do espírito de consumação entre os jovens, especialmente entre aqueles com baixa renda ou mesmo sem renda" (CORREA, 2008, p. 19).

Para Correa (2008), a criminalidade juvenil não pode ser explicada simplesmente pela relação entre o desejo de consumo e o poder de compra, inseparáveis a cultura de massa, citando ainda os efeitos perversos da globalização, da individualização para satisfação pessoal e da emancipação da família ligado aos novos estilos de vida. Cita como outro fator prejudicial o "efeito demonstração", numa lógica de consumação a todo preço, onde prevalece a criminalidade no submundo dos jovens desfavorecidos.

No Brasil, poucos jovens se beneficiam da globalização da economia, da sociedade do conhecimento e da cultura de massa. Esses jovens desempenham o papel de atores que antecipam o futuro de uma juventude sedenta por seguir a demonstração dos privilegiados do sistema. Toda uma economia subterrânea - na qual se coadunam atividades ilícitas como a prostituição, o jogo, o contrabando de mercadorias, notadamente aquelas falsificadas, o tráfico de armas e de drogas - se organiza à sombra do "efeito demonstração" (CORREA, 2008, p. 20).

O autor destaca ainda que "no contexto da modernidade reflexiva, a integração social dos jovens depende em grande parte do sucesso escolar e da inserção profissional" (CORREA, 2008, p. 12). O grande problema é que, para ingressar no mercado formal de trabalho os jovens precisam atender requisitos aos quais não foram preparados, especialmente em se tratando daqueles em situação de pobreza e vulnerabilidade social, cujas oportunidades de qualificação estão aquém da realidade do esperado.

A este respeito, Moreira, Sucena e Fernandes (2008, p. 157) citam o rol de exigências apresentado pelo Centro de Integração Empresa-Escola - CIEE em uma publicação intitulada "O profissional que faz a diferença" - Revista Agitação (1999). Para os autores, muitas delas “questionáveis ética e legalmente - por exemplo: (1) o que é ter 'boa aparência?', (2) o que é 'ser saudável?’, (3) quais os critérios que balizam a 'criatividade e a ambição'?".

Qualidades que as empresas procuram nos profissionais: boa apresentação, perspicaz/analítico, criativo/flexível, dinâmico/energético, responsável/dedicado; equilíbrio emocional; capacidade de atuar em equipe; ambicioso e ousado; perseverante; otimista/auto-motivado; conhecimento de informática; qualidade de 
vida/saudável; bom nível cultural; expressão oral e escrita; domínio de outros idiomas (MOREIRA; SUCENA; FERNANDES, 2008, p. 157).

Cabe revelar em contraposição, que durante os atendimentos da equipe da área infracional da 1a Vara da Infância e da Juventude, ao qual uma das autoras é integrante, ao serem questionados sobre sonhos e carreiras que gostariam de seguir no futuro, grande parte dos adolescentes respondem serem aquelas nas quais já tem alguma experiência e que não requer maiores níveis de escolaridade, quais sejam: mecânico, eletricista, pintor, ajudante de pedreiro, auxiliar de cozinha ou o "eterno padeiro da padaria" - resposta recente, entre outras, demonstrando certa estagnação diante de novas possibilidades, talvez levados pela consciência das limitações a eles impostas.

Os autores Moreira, Sucena e Fernandes (2008, p. 157) discorrem que até mesmo as ocupações menos valorizadas estão sendo negadas aos jovens, "reflexo da reestruturação global do mundo do trabalho, que, ao prescindir cada vez menos mão de obra e ao atrelar-se cada vez mais à política monetarista antiinflacionaria", acaba por precarizar as condições de trabalho, inviabilizar direitos trabalhistas, restringir a criação de novos postos e ocupações, desmobilizar sindicatos e, "sob o manto da 'qualidade total', amplia as exigências em relação ao trabalhador, fechando as portas para aqueles que não as atendem" (MOREIRA; SUCENA; FERNANDES, 2008, p. 157).

Segundo Correa (2008),

Quando se fala em inserção profissional, é preciso sublinhar que, para quase $40 \%$ dos jovens, o trabalho é uma necessidade. Entre os jovens de 15 a 24 anos, 36\% trabalham e 32\% estão desempregados. Os jovens são frequentemente subempregados, trabalham ilegalmente e em condições precárias ou de risco. Isso significa que o problema para os jovens não é somente o acesso ao emprego, mas também as condições de emprego (CORREA, 2008, p. 13).

A pesquisa com adolescentes em conflito com a lei corrobora com a fala dos autores. Ao analisar suas ocupações e condições de trabalho observadas nas falas dos mesmos, descritas nos processos judiciais, percebe-se que atuam de forma irregular, sem nenhuma garantia de proteção social, sem definição clara de carga horária, em condições precárias, perigosas ou insalubres e com baixos rendimentos devido inclusive ao nível de escolaridade exigido para a função. Muitos adolescentes iniciaram atividades levados por seus familiares mais próximos pais, tios, mães, como forma de ajudar no sustento do lar.

Em relação aos rendimentos, tanto do adolescente quanto dos responsáveis, não foi possível estabelecer um padrão de ganhos, primeiro que devido à pesquisa ser relativa aos últimos dez anos (2006 - 2016), os valores - muitos deles não informados por salário-mínimo 
podem ter ficado defasados e, segundo porque alguns recebem por diária, outros por semana, outros por quinzena, outros por mês. Além disso, percebe-se, durante as entrevistas da equipe interprofissional, que algumas famílias apresentam receio de fornecer o valor exato dos rendimentos, talvez por medo de perder benefícios sociais de transferência de renda ou outro, o que não poderia acontecer já que estes são de responsabilidade do poder executivo - política de assistência social e não do poder judiciário, ainda que fosse identificada alguma anomalia ou irregularidade, além da devida orientação às famílias, esta informação não poderia se caracterizar em prejuízo aos jurisdicionados.

A figura abaixo apresenta as principais ocupações dos adolescentes em conflito com a lei em Boa Vista - Roraima. Dos 550 processos/adolescentes representados, apenas 56 (10,18\%) informaram alguma ocupação e, em casos em que o adolescente informou mais de uma ocupação, foi considerada apenas a principal.

Foram contabilizadas 18 ocupações diferentes, agrupadas em 12 categorias, sendo que $15(26,8 \%)$ adolescentes informaram realizar atividades de ajudante de pedreiro, pintor ou jardineiro, 13 (23,2\%) como lavador de carros, 10 (17,9\%) como mecânico de motos, carros ou em pequenos consertos em oficinas de bicicletas, 3 (5,3\%) como doméstica ou auxiliar de cozinha, 3 (5,3\%) como serviços gerais (atividades de limpeza), 3 (5,3\%) como ajudante de serralheiro ou vidraceiro, $2(3,6 \%)$ como ajudante de eletricista, $2(3,6 \%)$ como vendedor ou porteiro, $2(3,6 \%)$ como vagueiro ou vigilante de carros, 1 (1,8\%) como aplicador de insulfilme, 1 $(1,8 \%)$ como auxiliar de serigrafia e $1(1,8 \%)$ como auxiliar de salão de beleza. 
Figura 16 - Ocupação do adolescente em conflito com a lei em Boa Vista - RR (2006-2016)

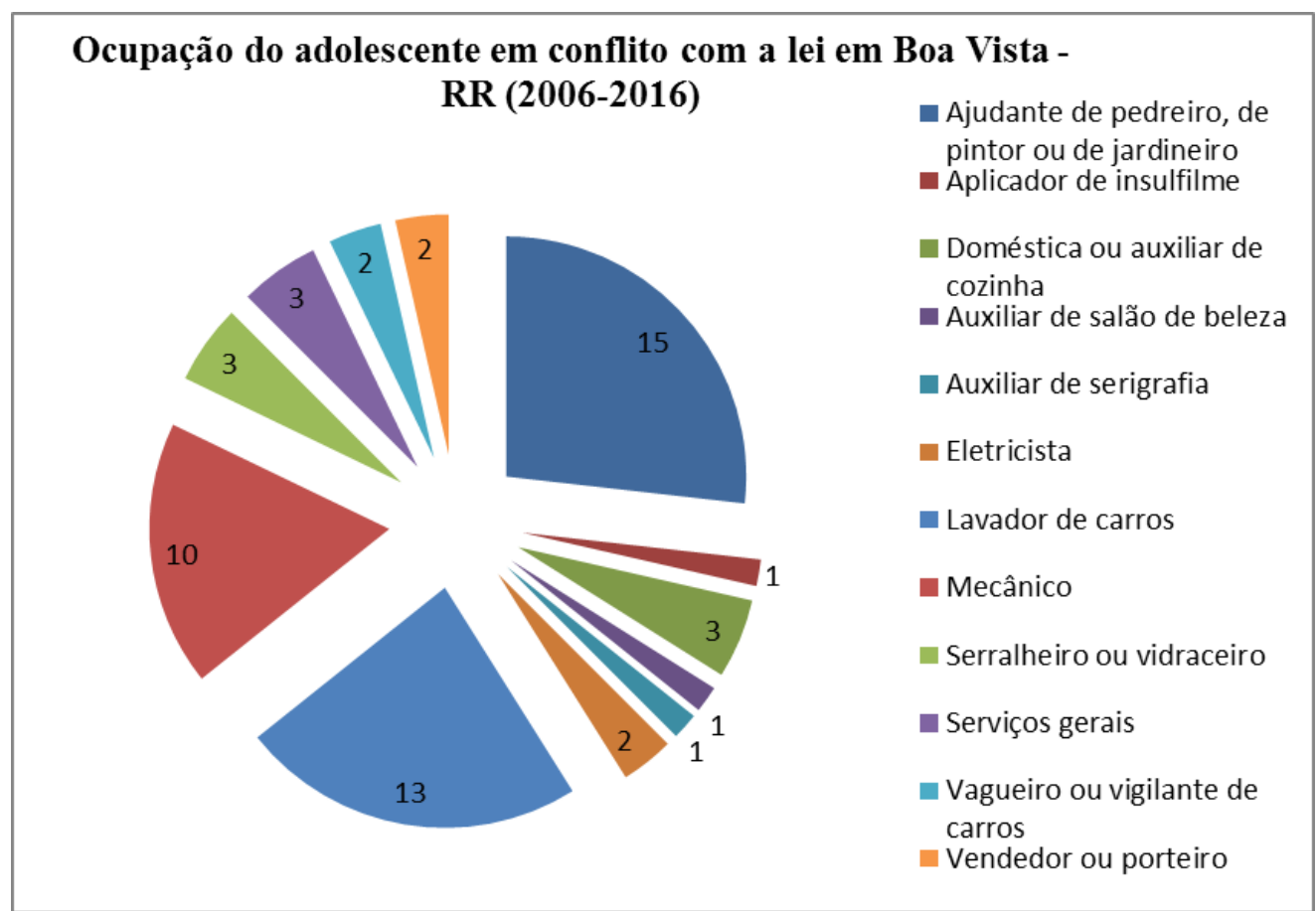

Fonte: Pesquisa realizada em processos judiciais de ato infracional na 1a Vara da Infância e da Juventude da Comarca de Boa Vista - Tribunal de Justiça do Estado de Roraima. Elaboração própria.

A figura 17 apresenta a ocupação dos pais ou responsáveis pelos adolescentes em conflito com a lei; aqui também foi considerada apenas uma ocupação por pais/responsáveis e, dos 550 processos analisados, apenas 199 (36,18\%) continham alguma informação sobre o tema, o que pode significar que mais da metade deles está fora do mercado de trabalho. Foram identificadas 54 profissões, elencadas em 30 categorias.

Segundo Yazbek (2004, p. 35), "a proporção de trabalhadores brasileiros que está fora do mercado formal de trabalho e, portanto, sem garantias de proteção social cresce continuamente e hoje ultrapassa mais da metade da população economicamente ativa", isto porque, vive-se "um contexto de subalternização do trabalho à ordem do mercado e de desmontagem de direitos sociais e trabalhistas" (YAZBEK, 2004, p. 35).

É interessante destacar algumas similaridades entre as ocupações dos pais ou responsáveis com as dos adolescentes. Observa-se que as profissões de trabalho doméstico e de construção civil são as que mais empregam ambos; esta prevalência justifica ainda o fato de que os adolescentes iniciam sua atividade laboral seguindo os exemplos dos pais ou responsáveis, dando continuidade a um ciclo que possivelmente tenha começado pelos seus avós e que, se não Ihes forem dadas oportunidades de escolarização, permeará a vida de seus filhos. Outra 
importante observação é que apenas $5(2,5 \%)$ dos pais ou responsáveis atuam em profissões cuja escolaridade exige, obrigatoriamente, o nível superior.

Este dado incide diretamente nas condições de empregabilidade (vínculos mais precários, proteção social, tempo de trabalho) e renda que, por sua vez, impacta nas condições de moradia, saúde, mobilidade, escolaridade, acesso a bens e serviços, exercício dos direitos sociais, número de filhos, conforto do lar, entre outros que corroboram com Abramo (2005, p. 52), ao afirmar, considerando os dados da pesquisa Perfil da juventude brasileira (2003), que "quanto mais o nível de escolaridade e renda dos pais é baixo, mais as condições de trabalho são precárias".

Figura 17 - Ocupação dos responsáveis pelos adolescentes em conflito com a lei em Boa Vista - RR (2006-2016)

\begin{tabular}{|l|c|c|l|c|c|}
\hline \multicolumn{1}{|c|}{ Ocupação } & Qtd. & $\%$ & \multicolumn{1}{|c|}{ Ocupação } & Qtd. & $\%$ \\
\hline Advogada, jornalista ou farmacêutico & 5 & 2,5 & Feirante & 1 & 0,5 \\
\hline $\begin{array}{l}\text { Agente de saúde ou técnica em } \\
\text { enfermagem }\end{array}$ & 10 & 5,0 & Funcionário público & 14 & 7,0 \\
\hline Agricultor ou vaqueiro & 4 & 2,0 & Guarda civil municipal & 1 & 0,5 \\
\hline $\begin{array}{l}\text { Almoxarife, auxiliar administrativo ou } \\
\text { secretária }\end{array}$ & 3 & 1,5 & Jardineiro & 2 & 1,0 \\
\hline Ambulante, autônomo ou artesã & 8 & 4,0 & Marmorista & 1 & 0,5 \\
\hline Aposentado & 8 & 4,0 & Mecânico ou serralheiro & 4 & 2,0 \\
\hline Cabeleireiro ou manicure & 7 & 3,5 & Militar & 2 & \\
\hline Caixa ou cobrador & 3 & 1,5 & $\begin{array}{l}\text { Pedreiro, pintor ou } \\
\text { eletricista }\end{array}$ & 18 & 9,0 \\
\hline Costureira & 1 & 0,5 & Pescador & 2 & 1,0 \\
\hline $\begin{array}{l}\text { Cozinheira, garçonete, merendeira, } \\
\text { salgadeira ou auxiliar de cozinha }\end{array}$ & 14 & 7,0 & Professor & 5 & 2,5 \\
\hline Dedetizador & 1 & 0,5 & Serviços gerais ou gari & 22 & 11,0 \\
\hline Desempregado/a & 4 & 2,0 & Taxista ou motorista & 3 & 1,5 \\
\hline Doméstica ou diarista & 37 & 18,6 & Topógrafo & 1 & 0,5 \\
\hline Embalador ou repositor & 2 & 1,0 & $\begin{array}{l}\text { Vendedor, empresário, } \\
\text { encarregado ou } \\
\text { comerciante }\end{array}$ & 14 & 7,0 \\
\hline Estagiária & 1 & 0,5 & Vigilante & 1 & 0,5 \\
\hline Fonte
\end{tabular}

Fonte: Pesquisa realizada em processos judiciais de ato infracional na 1a Vara da Infância e da Juventude da Comarca de Boa Vista - Tribunal de Justiça do Estado de Roraima. Elaboração própria.

Destaque-se que mais de 90\% dos pais ou responsáveis afirma ser beneficiário de pelo menos um benefício de transferência de renda (embora possa se beneficiar de mais de um), o que indica sua situação de pobreza. Os benefícios socioassistenciais referem-se ao Programa 
Bolsa Família - PBF do Governo Federal e Programa Crédito do Povo (nome atualizado do Programa Vale-alimentação e do Programa Crédito Social) do Governo do estado de Roraima.

Yazbek (2004) classifica este tipo de programa como sendo residuais, que não fazem referência a direitos e que não passam de ações solidarias e filantrópicas que na realidade não mudam a vida das pessoas. Significam, segundo a autora, uma filantropia revisitada pelos neoliberais, que reduzem os recursos para a área social e implantam, em contrapartida, políticas de matriz conservadora, oligárquica e patrimonialista e com perfil clientelista e assistencialista que transforma o que é direito em favor.

É bom lembrar ainda que a pobreza é uma face do descarte da mão de obra barata, que faz parte da expansão capitalista. Expansão que cria uma população sobrante que se tornou não empregável, parcelas crescentes de trabalhadores que não encontram um lugar reconhecido na sociedade, que transitam à margem do trabalho e das formas de troca socialmente reconhecidas (TELLES, 1998). Expansão que cria o necessitado, o desamparado e a tensão permanente da instabilidade no trabalho. Implica a disseminação do desemprego de longa duração, do trabalho precário, instável e intermitente, dos biscates e de outras modalidades de relacionamento da forca de trabalho com o capital, que em sua essência representam uma mesma ordenação da vida social (YAZBEK, 2004, p. 35).

Ainda de acordo com Yazbek (2004, p. 35), "a violência da pobreza é parte da nossa experiência diária" e é a população empobrecida quem sofre mais diretamente os impactos destrutivos do capitalismo contemporâneo:

[...] o aviltamento do trabalho, o desemprego, os empregados de modo precário e intermitente, o que se tornaram não empregáveis e supérfluos, a debilidade da saúde, o desconforto da moradia precária e insalubre, a alimentação insuficiente, a fome, a fadiga, a ignorância, a resignação, a revolta, a tensão e o medo são sinais que muitas vezes anunciam os limites da condição de vida dos excluídos e subalternizados na sociedade (YAZBEK, 2004, p. 35).

De acordo com Correa (2008, p. 12), assim como as crianças, os adultos e os idosos, os jovens também estabelecem laços sociais. "Para a maioria, esses laços são tecidos em condições de trabalho precárias e em relações primárias nos grupos ou nas comunidades de pertencimento de origem". Para o autor, "no Brasil, a individualização se intensifica sem por isso emancipar os jovens dos pertencimentos típicos às suas relações primárias" (CORREA, 2008, p. 12). Ainda que a mudança no significado de família tenha gerado, nas últimas décadas, novas configurações familiares, "para os jovens brasileiros, os pertencimentos originais (à família, ao grupo étnico ou religioso, à região e ao bairro enquanto "espaço vivido")" podem ser o lugar da segurança (CORREA, 2008, p. 12). 
De acordo com a pesquisa, os adolescentes em conflito com a lei estão sob responsabilidade de seus pais ou familiares, sendo que, alguns deles, vivem aos cuidados de amigos mais velhos, sozinhos ou sob a tutela do estado em instituições de acolhimento ou unidade socioeducativa.

Figura 18 - Responsável pelo adolescente em conflito com a lei em Boa Vista RR (2006-2016)

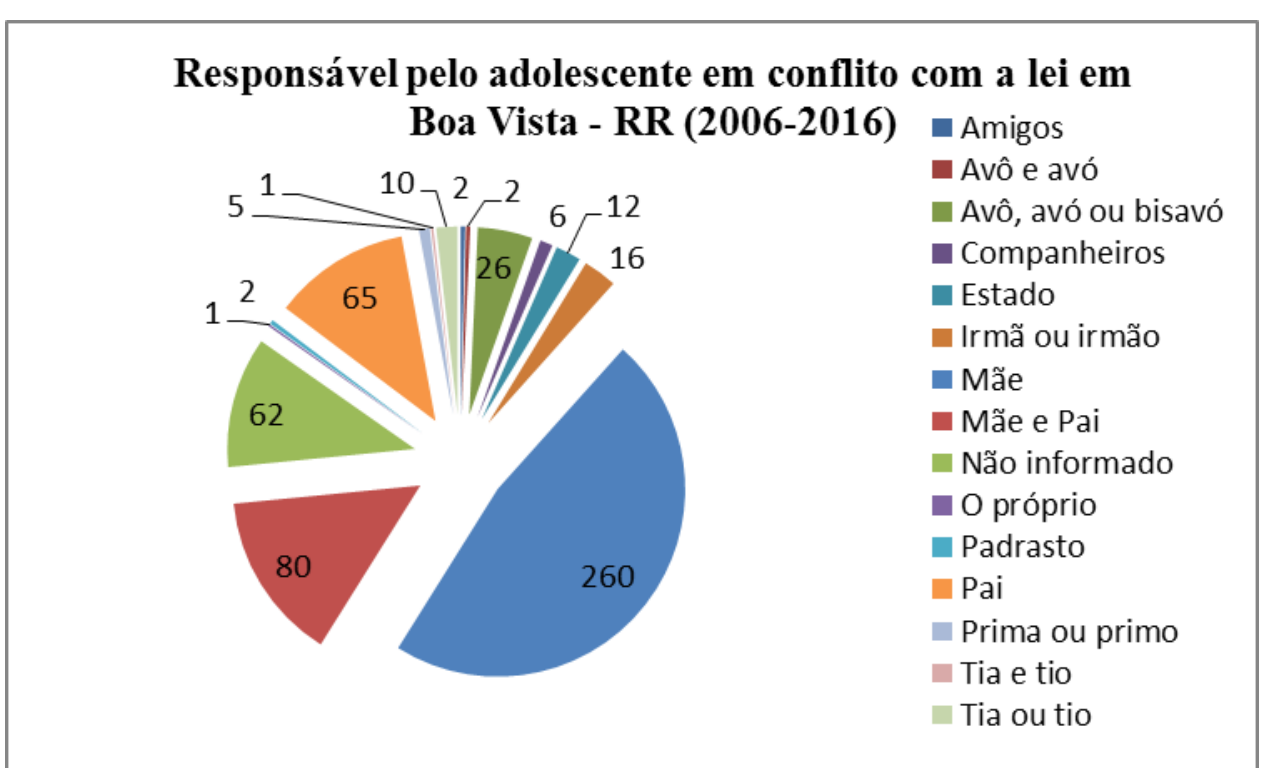

Fonte: Pesquisa realizada em processos judiciais de ato infracional na 1a Vara da Infância e da Juventude da Comarca de Boa Vista - Tribunal de Justiça do Estado de Roraima. Elaboração própria.

Dos 550 adolescentes pesquisados, 260 (47,2\%) vivem sob a responsabilidade das mães, 80 (14,5\%) dos pais (mãe e pai), 65 (11,8\%) do pai, 26 (4,7\%) do avô, avó ou bisavó, 16 (2,9\%) do irmão ou irmã, 12 (2,2\%) vivem estão sob a tutela do estado em instituição de acolhimento ou unidade socioeducativa, o que retrata uma conduta infracional ou a reincidência desta, mesmo estando na responsabilidade do poder público, 10 (1,8\%) vivem sob os cuidados de tia ou tio, 5 $(0,9 \%)$ de prima ou primo, $6(1,1 \%)$ vivem com companheiros maiores de 18 anos que de alguma forma são as pessoas que acompanham em delegacia ou juizado da infância - mesmo que não haja nada formalmente instituído, $2(0,4 \%)$ vivem sob os cuidados do padrasto, $2(0,4 \%)$ com avô e avó, 2 (0,4\%) com amigos, 1 (0,2\%) vive sozinho e assume ser seu próprio responsável, 1 (0,2\%) com tia e tio e 62 (11,3\%) não foram informados. 
Figura 19 - Responsável pelo adolescente em conflito com a lei em Boa Vista RR por sexo (2006-2016)

\section{Responsável pelo adolescente em conflito com a lei em Boa Vista - RR por sexo (2006-2016)}

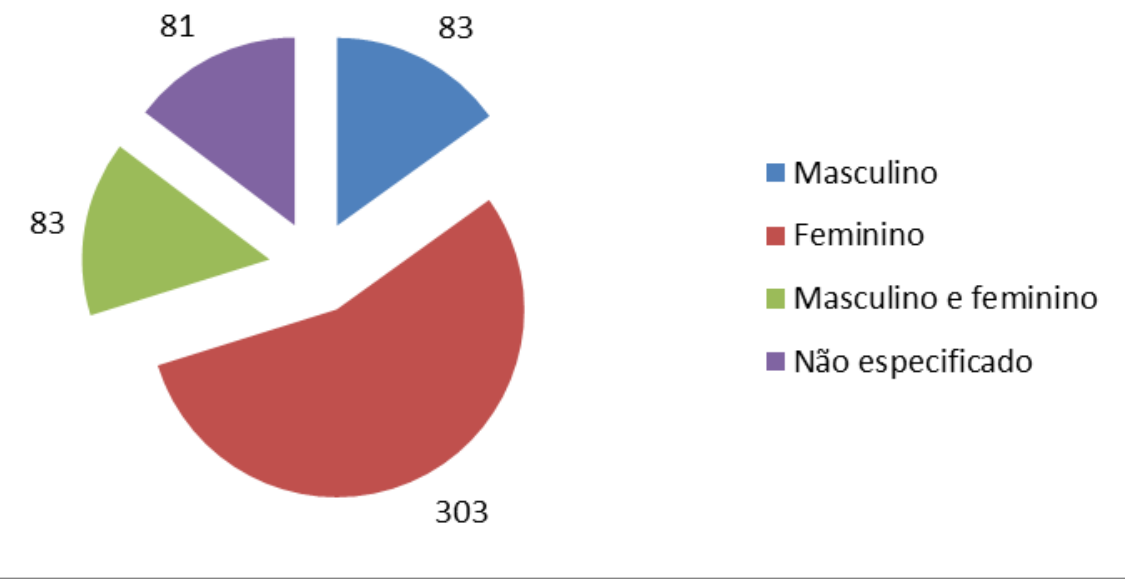

Fonte: Pesquisa realizada em processos judiciais de ato infracional na 1a Vara da Infância e da Juventude da Comarca de Boa Vista - Tribunal de Justiça do Estado de Roraima. Elaboração própria.

O levantamento, por sexo, dos responsáveis pelos adolescentes, mostra que 303 (55\%) estão aos cuidados de mulheres, $83(15,1 \%)$ aos cuidados de homens e mulheres, 83 (15,1\%) somente de homens e $81(14,7 \%)$ não informados ou não especificados. O número de mulheres que, sozinhas, são responsáveis pelos adolescentes em conflito com a lei - sejam filhos, netos, sobrinhos, irmãos ou outro sobe ainda mais se isolá-las nos casos em que vivem com o companheiro ou se considerasse os dados que estão indefinidos. Esta realidade corrobora, em parte, com as demais localidades brasileiras, segundo pesquisa do CNJ (2012) - Figura 20.

Pires, Matos, Cerqueira, Figueiredo e Sousa (2004), ao evidenciar as características estruturais e funcionais das famílias multiproblemáticas pobres, sugerem que estas se organizam em dez categorias: comunicação confusa, indefinição do agregado familiar, mulheres como figuras centrais, mortes trágicas, baixas qualificações acadêmicas, trabalho infantil, trajetórias profissionais instáveis, elevada mobilidade geográfica, problemas de saúde e relações conflituosas. As autoras destacam que uma ou mais destas categorias podem também ser encontradas isoladas em famílias que não estão associação à pobreza ou ao baixo status social. O que as diferencia é que nas famílias pobres sua presença torna-se mais séria devido a longa duração e forte intensidade, além de estarem entrelaçadas. 
Figura 20 - Responsáveis pela criação do adolescente em conflito com a lei em âmbito nacional

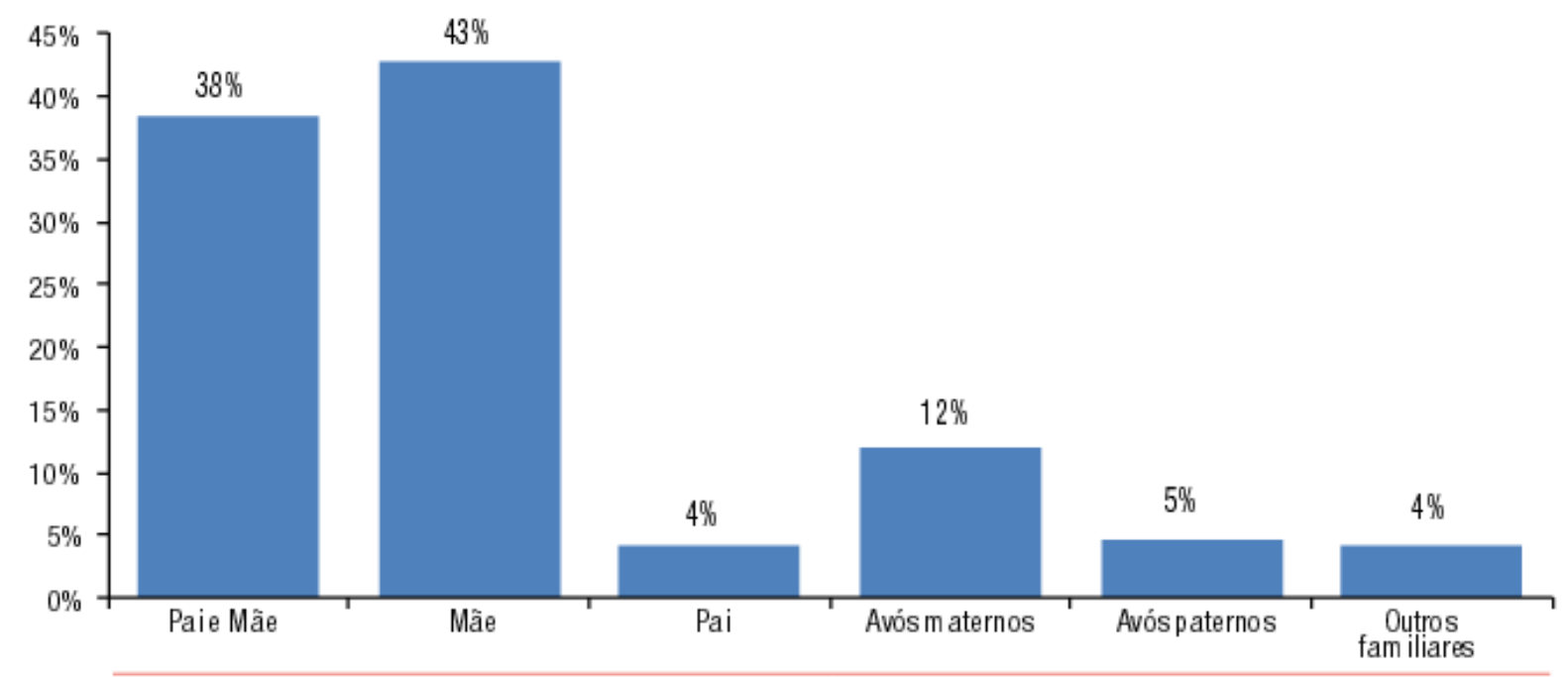

Fonte: CNJ (2012, p. 18). a possibilidade de o adolescente ter sido criado por mais de um ente familiar explica o fato de o total das porcentagens somar mais de $100 \%$.

De acordo com Correa (2008, p. 15-16), "no Brasil, os jovens em busca de emancipação devem contar com eles mesmos e com suas redes sociais, sendo estas últimas reduzidas à família, à vizinhança e à comunidade local". Neste sentido, o autor estabelece um paradoxo: deixar quem o auxilia pode ser benéfico ao passo que pode gerar emancipação individual ou o contrário, pois implica compromissos.

Para o autor, "são as relações sociais intra e intergeracionais e intra e interclasses sociais que definem, grosso modo, o campo social no qual várias estratégias de reprodução social são colocadas em prática" (CORREA, 2008, p. 16) e estabelece, citando Pierre Bourdieu, que "os jovens brasileiros herdam, em grande parte, o seu capital econômico e cultural diretamente no contexto familiar" (CORREA, 2008, p. 16), sendo que [...] "a constituição da sociedade implica a socialização dos indivíduos e a sociedade democrática requer indivíduos emancipados" (CORREA, 2008, p. 16).

O processo de individualização é, portanto, inexorável e se inscreve em outros processos (de massificação cultural, de mundialização e transformação da sociedade de consumo). Disso decorre um desafio para os jovens brasileiros: como se tornar um indivíduo emancipado numa sociedade marcada por desigualdades e onde as relações secundárias (ou formais, como, por exemplo, na escola ou no trabalho) não logram exercer algumas funções ainda sob o controle das relações primárias (ou informais, como, por exemplo, aquelas familiares ou de vizinhança)? (CORREA, 2008, p. 14). 
Correa (2008) afirma ainda que a ideia de "indivíduos afiliados", ou seja, o vínculo de pertencimento à família representa certa para o jovem certa proteção social. Contudo, "a herança social, o pertencimento familiar, o vínculo ao bairro e ao seu microcosmo podem encerrar mais ainda os jovens desfavorecidos em sua condição de origem" (CORREA, 2008, p. 21).

Em relação à naturalidade dos adolescentes, 21 (3,82\%) migraram do estado do Amazonas, 4 (0,72\%) do Ceará, 2 (0,36\%) de Goiás, 39 (7,1\%) do Maranhão, 1 (0,18\%) do Mato Grosso do Sul, 33 (6\%) do Pará, 1 (0,18\%) do Paraná, 3 (0,54\%) do Rio Grande do Norte, 6 (1,1\%) de Rondônia, 418 (76\%) nasceram em Roraima, 9 (1,64\%) de São Paulo e 2 (0,36\%) são do país vizinho Venezuela. Dos 550 processos pesquisados, não se obteve informações sobre naturalidade de $11(2 \%)$.

Figura 21 - Naturalidade dos adolescentes em conflito com a lei em Boa Vista RR (2006-2016)

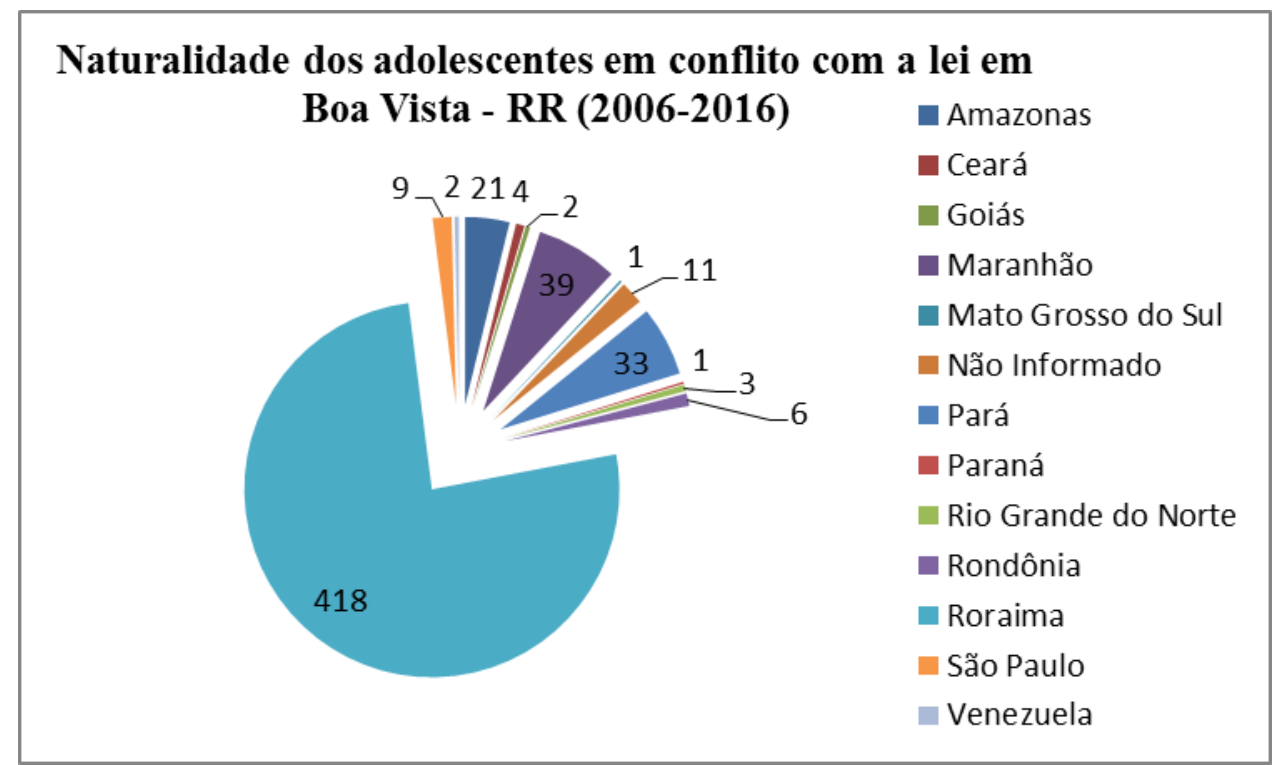

Fonte: Pesquisa realizada em processos judiciais de ato infracional na 1a Vara da Infância e da Juventude da Comarca de Boa Vista - Tribunal de Justiça do Estado de Roraima. Elaboração própria.

A diversidade de naturalidade dos adolescentes se justifica em grande medida pela intensa migração ocorrida no estado nas últimas décadas (informação discutida em outro capítulo da tese). Além disso, a proximidade de 231 quilômetros com a fronteira da Venezuela (Santa Elena de Uairén), ao norte do estado, favorece a entrada e permanência de jovens estrangeiros na capital Boa Vista. 
Em se considerando a naturalidade por região brasileira, tem-se que 478 (86,92\%) são naturais da região Norte, $46(8,36 \%)$ são da região Nordeste, $3(0,54)$ são da região CentroOeste, $9(1,64 \%)$ da região Sudeste, $1(0,18 \%)$ da região Sul. Os 13 adolescentes restantes $(2,36 \%)$ são estrangeiros ou de naturalidade não informada.

Figura 22 - Naturalidade dos adolescentes em conflito com a lei em Boa Vista RR por região brasileira (2006-2016)

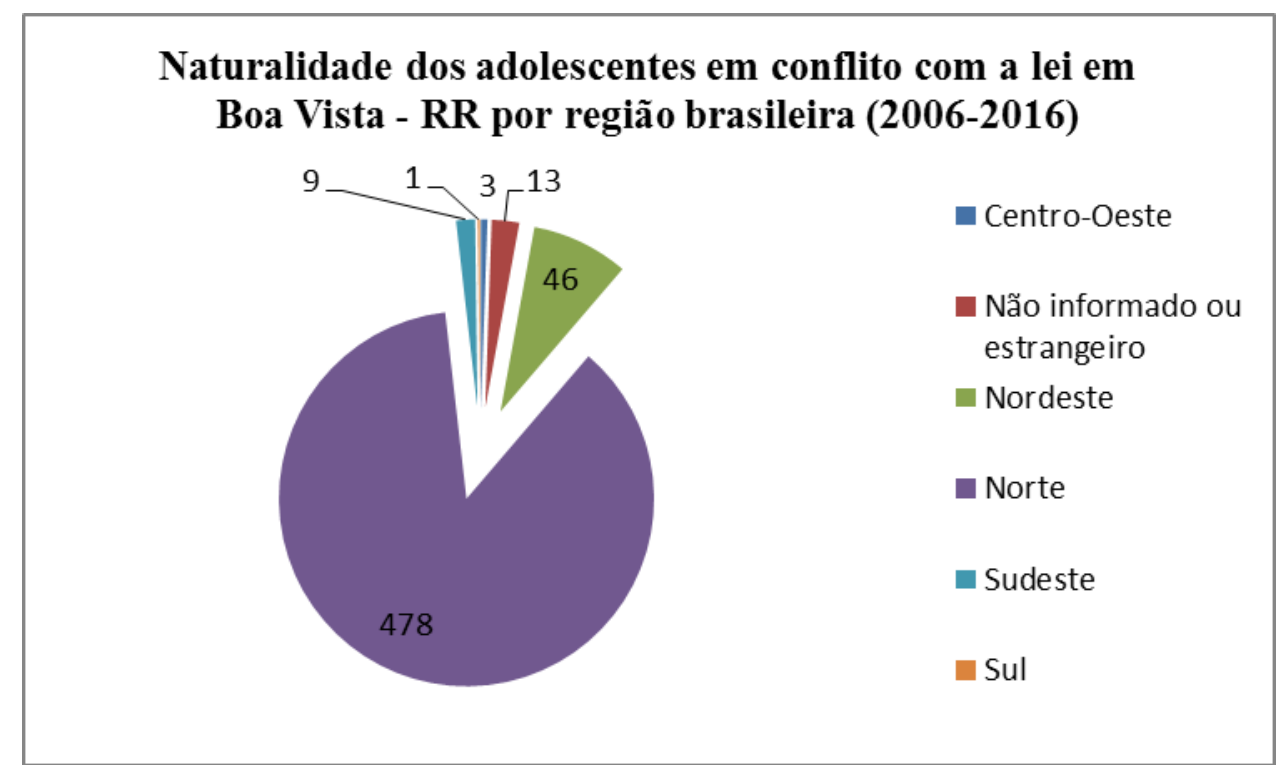

Fonte: Pesquisa realizada em processos judiciais de ato infracional na 1a Vara da Infância e da Juventude da Comarca de Boa Vista - Tribunal de Justiça do Estado de Roraima. Elaboração própria.

A naturalidade, por estado, dos responsáveis pelos adolescentes em conflito com a lei, apresentou maior diversidade de localidades, se comparado aos adolescentes. Neste quesito, foi considerada a naturalidade de um único responsável, geralmente aquele que acompanhou o adolescente na delegacia e cujos dados constavam no registro do Boletim de Ocorrência ou que estava com ele no momento da entrevista da equipe interprofissional da 1a VIJ/TJRR.

A pesquisa revelou que $5(0,9 \%)$ responsáveis são naturais do Acre, $25(4,54 \%)$ do Amazonas, 1 da Bahia (0,18\%), 15 (2,72\%) do Ceará, 4 (0,72\%) do Distrito Federal, 2 (0,36\%) do Espírito Santo, 100 (18,18\%) do Maranhão, 2 (0,36\%) do Mato Grosso, 44 (8\%) do Pará, 2 (0,36\%) da Paraíba, $3(0,54 \%)$ do Paraná, 3 (0,54\%) de Pernambuco, 4 (0,72\%) do Piauí, 2 $(0,36 \%)$ do Rio de Janeiro, 1 (0,18\%) do Rio Grande do Norte, 6 (1,1\%) de Rondônia, 154 (28\%) nasceram em Roraima, 4 (0,72\%) de São Paulo e 3 (0,54\%) são estrangeiros provenientes de Camarões, Itália e Peru. Além destes, 170 (31\%) processos não continham a informação da naturalidade dos responsáveis. 
Figura 23 - Naturalidade dos responsáveis pelos adolescentes em conflito com a lei em Boa Vista - RR (2006-2016)

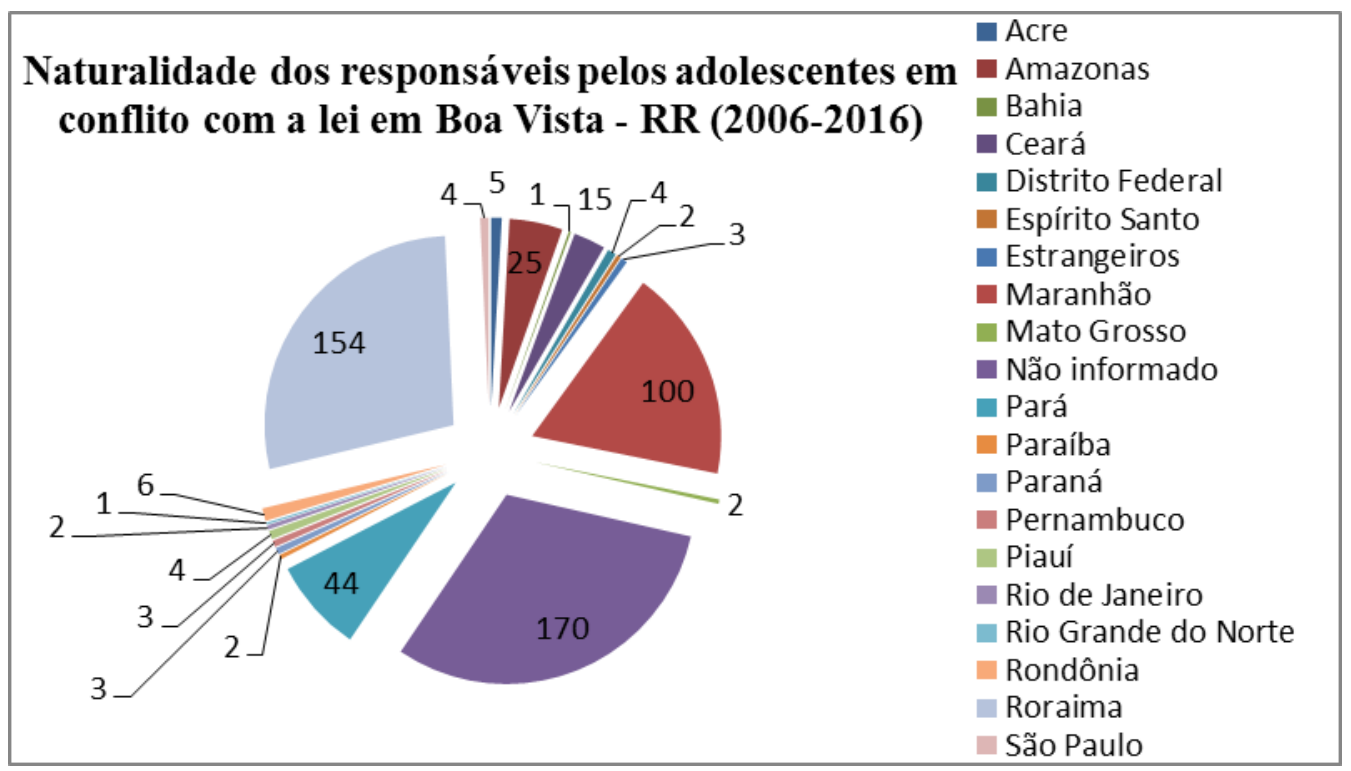

Fonte: Pesquisa realizada em processos judiciais de ato infracional na 1ạ Vara da Infância e da Juventude da Comarca de Boa Vista - Tribunal de Justiça do Estado de Roraima. Elaboração própria.

Figura 24 - Naturalidade dos responsáveis pelos adolescentes em conflito com a lei em Boa Vista - RR por região brasileira (2006-2016)

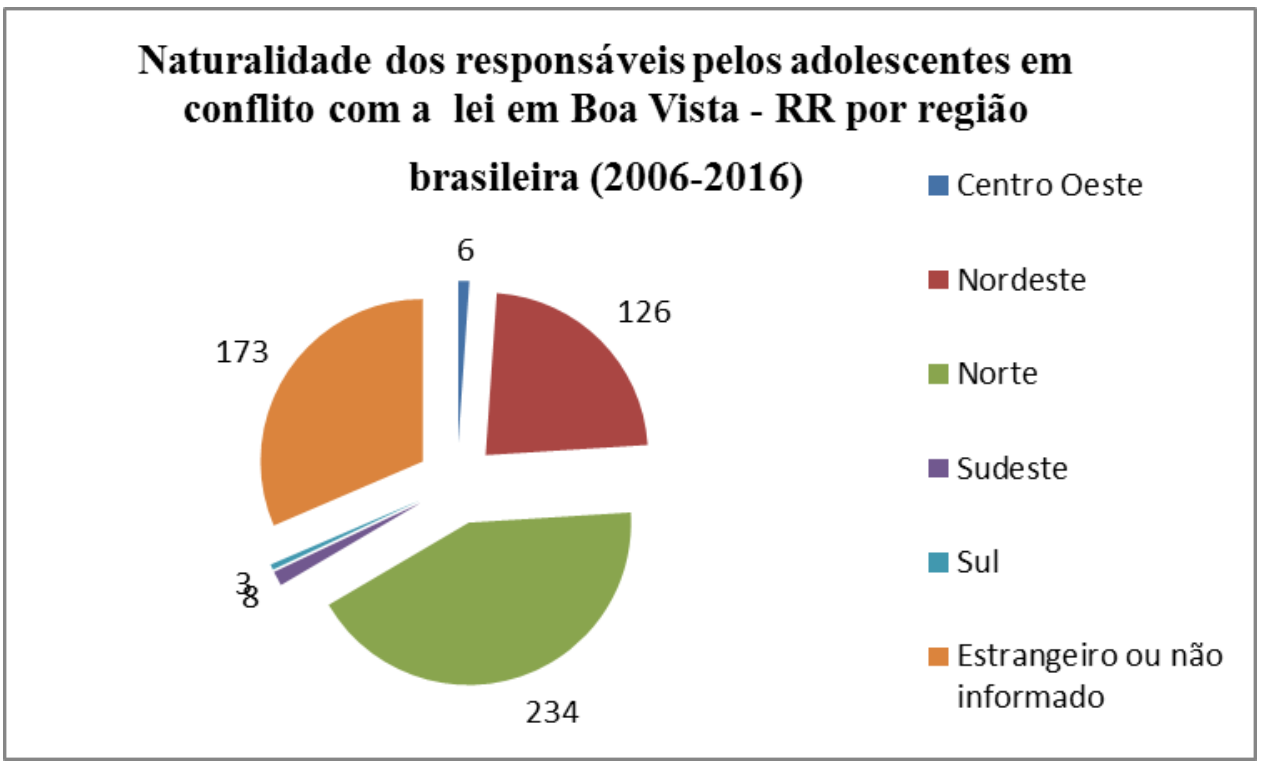

Fonte: Pesquisa realizada em processos judiciais de ato infracional na 1ạ Vara da Infância e da Juventude da Comarca de Boa Vista - Tribunal de Justiça do Estado de Roraima. Elaboração própria.

Por região brasileira, 234 (42,5\%) responsáveis são do Norte do Brasil, 126 (23\%) do Nordeste, $8(1,5 \%)$ do Sudeste, $6(1 \%)$ do Centro-Oeste, $3(0,5 \%)$ do Sul e $173(31,5 \%)$ são estrangeiros ou não informados. 
A naturalidade dos responsáveis remete à pesquisa de Diniz (2008) quando demonstra que os principais estados de origem dos imigrantes de Roraima entre os anos de 1975 a 2000 são o Maranhão, o Pará e o Amazonas e o principal destino, no mesmo período, era a capital Boa Vista

Dos bairros de residência dos adolescentes em conflito com a lei em Boa Vista - RR identificados nos 550 processos de Procedimento Apuratório de Ato Infracional, 6 (1,1\%) são do Centro, 4 (0,7\%) são da Zona Leste, $22(4 \%)$ da Zona Sul, 35 (6,4\%) da Zona Norte e 483 (87,8\%) da Zona Oeste, assim distribuídos:

1. Zona Leste: 1 adolescente do bairro Canarinho e 3 do Paraviana;

2. Zona Sul: 3 adolescentes residem no bairro Calungá, 1 no Distrito Industrial Governador Aquilino Mota Duarte, 10 no São Vicente e 8 no Treze de Setembro;

3. Zona Norte: 2 adolescentes residentes no bairro Aeroporto, 5 no Nossa Senhora Aparecida, 19 no Cauamé, 4 no Calungá, 3 no bairro dos Estados, 1 no São Francisco e 1 no 31 de março;

4. Zona Oeste: 11 adolescentes do bairro Alvorada, 14 do bairro Professora Araceli Souto Maior, 22 do Asa Branca, 14 do Bela Vista, 13 do Buritis, 8 do Caimbé, 7 do Cambará, 19 do Caranã, 3 do Centenário, 15 do Cidade Satélite, 16 do Cinturão Verde, 30 no Doutor Silvio Botelho, 18 no Doutor Silvio Leite, 11 no Jardim Caranã, 23 no Jardim Equatorial, 5 no Jardim Floresta, 16 no Jardim Primavera, 8 no Jardim Tropical, 8 no Jóquei Clube, 19 do Laura Moreira, 19 no Liberdade, 16 no Mecejana, 7 no Nova Canaã, 9 no Nova Cidade, 5 no Olímpico, 5 no Operário, 27 no Pintolândia, 4 no Psicultura, 5 no Pricumã, 12 no Raiar do Sol, 8 no Santa Luzia, 14 no Santa Tereza, 9 no São Bento, 47 no Senador Hélio Campos, 10 no Tancredo Neves e 6 no União.

Interessa notar que, de acordo com pesquisa das autoras, Senador Hélio Campos destaca-se por ser o bairro com maior quantidade de registros de ocorrências de ato infracional em Boa Vista - Roraima, em tempo que se apresenta também com o maior número de adolescentes em conflito com a lei residindo no bairro ou em suas proximidades. 
Figura 25 - Adolescentes em conflito com a lei por bairro de residência em Boa Vista - RR (2006-2016)

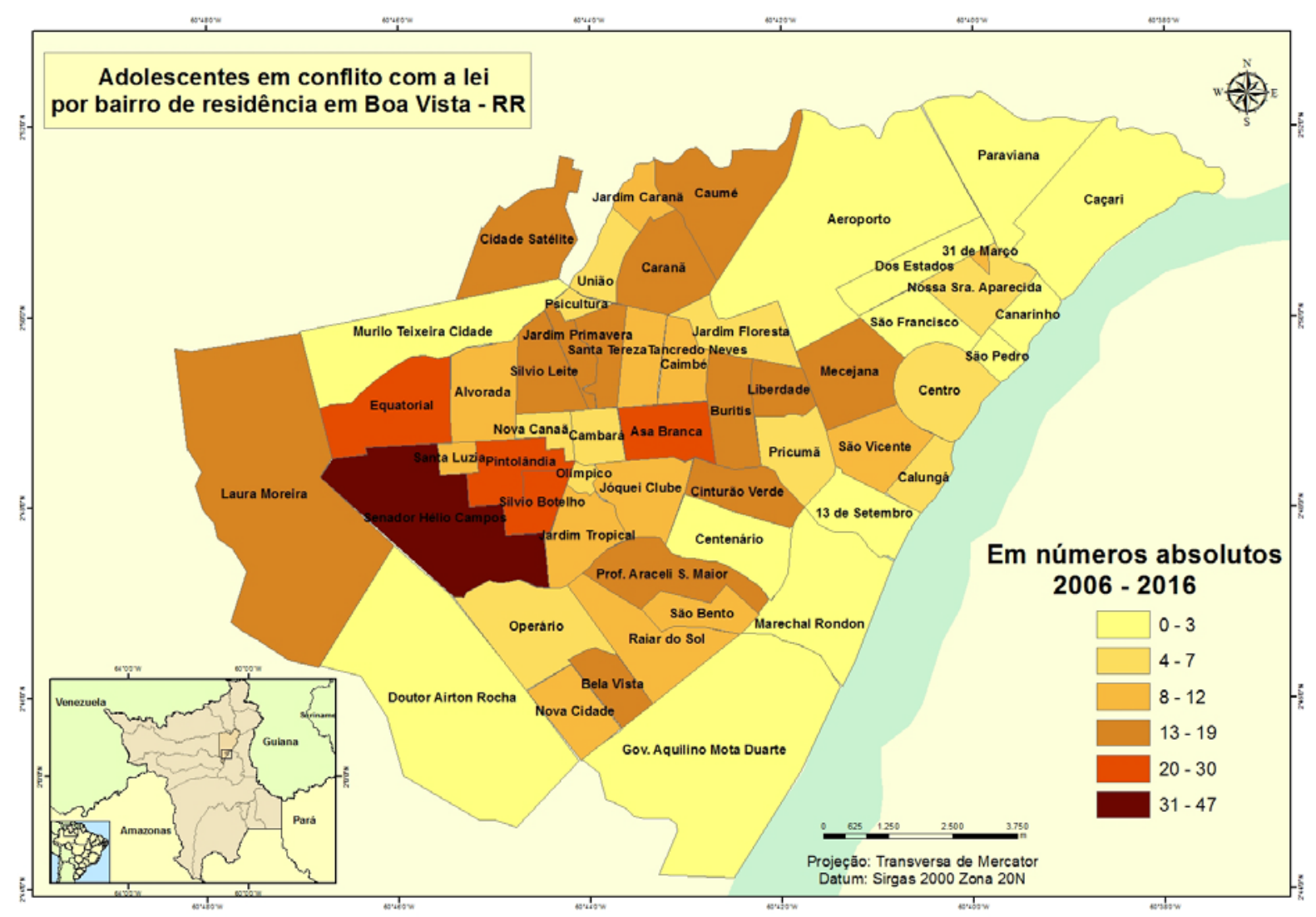

Fonte: Pesquisa realizada em processos judiciais de ato infracional da 1a Vara da Infância e da Juventude da Comarca de Boa Vista - RR. Elaboração: Janaine Voltolini de Oliveira/Roberto Helber Correia Alves.

Ao tentar compreender esta relação, buscou-se informações do Censo Demográfico do IBGE (2010) que demonstram, a partir dos dados de população residente, taxa de alfabetização, rendimento nominal e quantitativo de domicílios permanentes, que os bairros que mais se destacam pelas ocorrências de ato infracional são justamente aqueles que apresentam maior densidade demográfica, menores taxas de alfabetização, menor rendimento nominal e maior número de domicílios.

Evidenciando os cinco "piores" índices de cada indicador, é possível averiguar que o bairro Senador Hélio Campos se destaca por ser o único bairro de Boa Vista a condensar todos eles. 
Figura 26 - População residente, taxa de alfabetização e rendimento nominal de pessoas com 10 anos ou mais e domicílios particulares permanentes por bairro em Boa Vista - RR (2010)

\begin{tabular}{|c|c|c|c|c|}
\hline Bairro & $\begin{array}{l}\text { População } \\
\text { residente }\end{array}$ & $\begin{array}{c}\text { Taxa de } \\
\text { alfabetização das } \\
\text { pessoas de } 10 \text { anos } \\
\text { ou mais (\%) }\end{array}$ & $\begin{array}{c}\text { Rendimento } \\
\text { nominal médio } \\
\text { mensal - } 10 \text { anos ou } \\
\text { mais de idade }\end{array}$ & $\begin{array}{c}\text { Domicílios } \\
\text { particulares } \\
\text { permanentes }\end{array}$ \\
\hline 5 de outubro & 1.542 & 99,5 & $3.131,69$ & 490 \\
\hline Aeroporto & 3.348 & 96,1 & 873,17 & 930 \\
\hline Alvorada & 7.914 & 93,4 & 474,84 & 2.034 \\
\hline Asa Branca & 5.256 & 94,6 & 640,17 & 1.381 \\
\hline Bela Vista & 3.084 & 92,2 & 448,48 & 827 \\
\hline Buritis & 9.305 & 95,1 & 805,01 & 2.548 \\
\hline Caçari & 3.254 & 99,5 & $3.148,17$ & 952 \\
\hline Caimbé & 7.447 & 97,5 & 904,56 & 2.068 \\
\hline Calungá & 2.236 & 97,5 & 909,54 & 558 \\
\hline Cambará & 9.488 & 95,2 & 714,01 & 2.585 \\
\hline Canarinho & 710 & 99,2 & $1.961,34$ & 187 \\
\hline Caranã & 9.931 & 96,1 & 710,77 & 2.654 \\
\hline Cauamé & 7.480 & 95,1 & 697,20 & 1.945 \\
\hline Centenário & 5.497 & 96,7 & 722,71 & 1.490 \\
\hline Centro & 5.140 & 97,7 & $1.441,84$ & 1.632 \\
\hline Cidade Satélite & 5.942 & 94,5 & 471,77 & 1.624 \\
\hline Cinturão Verde & 5.907 & 97,4 & 932,84 & 1.654 \\
\hline Dos Estados & 4.639 & 97,5 & $1.273,03$ & 1.241 \\
\hline $\begin{array}{l}\text { Doutor Airton } \\
\text { Rocha }\end{array}$ & 69 & 98,1 & 914,78 & 20 \\
\hline $\begin{array}{ll}\text { Dr. } & \text { Silvio } \\
\text { Botelho } & \end{array}$ & 7.188 & 92,3 & 419,77 & 1.804 \\
\hline Dr. Silvio Leite & 8.849 & 95,0 & 521,37 & 2.312 \\
\hline $\begin{array}{l}\text { Governador } \\
\text { Aquilino Mota } \\
\text { Duarte }\end{array}$ & 519 & 90,6 & 428,78 & 122 \\
\hline Jardim Caranã & 3.495 & 90,4 & 470,36 & 890 \\
\hline $\begin{array}{l}\text { Jardim } \\
\text { Equatorial }\end{array}$ & 5.594 & 93,8 & 410,65 & 1.419 \\
\hline Jardim Floresta & 4.546 & 97,2 & $1.226,06$ & 1.392 \\
\hline $\begin{array}{l}\text { Jardim } \\
\text { Primavera }\end{array}$ & 6.186 & 92,9 & 465,57 & 1.554 \\
\hline Jardim Tropical & 2.073 & 92,3 & 508,07 & 566 \\
\hline Jóquei Clube & 6.515 & 95,6 & 680,11 & 1.716 \\
\hline Laura Moreira & 4.992 & 91,3 & 315,96 & 1.237 \\
\hline Liberdade & 6.199 & 96,6 & 883,30 & 1.866 \\
\hline Mecejana & 6.134 & 98,4 & $1.536,69$ & 1.862 \\
\hline $\begin{array}{l}\text { Murilo Teixeira } \\
\text { Cidade }\end{array}$ & 112 & 92,4 & 719,13 & 29 \\
\hline
\end{tabular}




\begin{tabular}{|c|c|c|c|c|}
\hline $\begin{array}{l}\text { Nossa Senhora } \\
\text { Aparecida }\end{array}$ & 4.860 & 97,8 & $1.528,10$ & 1.545 \\
\hline Nova Canaã & 6.007 & 94,8 & 484,33 & 1.585 \\
\hline Nova Cidade & 5.708 & 90,7 & 385,35 & 1.450 \\
\hline Olímpico & 915 & 94 & 346,25 & 235 \\
\hline Operário & 2.521 & 90,4 & 442,51 & 626 \\
\hline Paraviana & 5.443 & 99,0 & $2.579,00$ & 1.609 \\
\hline Pintolândia & 10.990 & 92,8 & 376,29 & 2.786 \\
\hline Pricumã & 7.051 & 98,3 & $1.493,06$ & 1.986 \\
\hline $\begin{array}{l}\text { Professora } \\
\text { Araceli Souto } \\
\text { Maior }\end{array}$ & 4.102 & 90,8 & 366,56 & 1.029 \\
\hline Psicultura & 1.471 & 92,1 & 456,34 & 363 \\
\hline Raiar do Sol & 5.863 & 91,9 & 443,97 & 1.515 \\
\hline Santa Luzia & 8.777 & 91,6 & 351,54 & 2.258 \\
\hline Santa Tereza & 8.118 & 93,6 & 475,92 & 2.127 \\
\hline São Bento & 6.368 & 92,1 & 309,79 & 1.659 \\
\hline São Francisco & 3.992 & 98,3 & $2.003,33$ & 1.190 \\
\hline $\begin{array}{l}\text { São } \\
\text { Pedro }\end{array}$ & 985 & 99,1 & $1.699,32$ & 289 \\
\hline São Vicente & 6.222 & 96,3 & $1.027,61$ & 1.734 \\
\hline $\begin{array}{l}\text { Senador Hélio } \\
\text { Campos }\end{array}$ & 10.010 & 90,2 & 356,12 & 2.504 \\
\hline $\begin{array}{l}\text { Tancredo } \\
\text { Neves }\end{array}$ & 7.007 & 95,3 & 616,46 & 1.835 \\
\hline $\begin{array}{ll}\text { Treze } & \text { de } \\
\text { Setembro }\end{array}$ & 4.643 & 95,0 & 751,23 & 1.253 \\
\hline $\begin{array}{l}\text { Trinta e um de } \\
\text { março }\end{array}$ & 1.631 & 96,7 & $1.341,59$ & 506 \\
\hline União & 3.801 & 93,7 & 463,72 & 958 \\
\hline
\end{tabular}

Fonte: Censo Demográfico IBGE 2010. Organizado pelas autoras.

Sobre o uso ${ }^{6}$ e/ou abuso de substâncias psicoativas, na pesquisa realizada com os adolescentes em conflito com a lei em Boa Vista, 501 (91\%) deles afirmam já ter experimentado ou fazer uso de algum tipo de substância psicoativa - lícita (cigarro, cerveja, cachaça, whisky ou vodka) ou ilícita (maconha, crack, cocaína e skunk são os mais citados). A este respeito, Libânio (2004, p. 48) afirma que:

[...] o mundo moderno neoliberal caracteriza-se por crescente segregação. As maiores vítimas são os jovens. Sentem na carne que a modernidade os repele. Confina-os em instituições educacionais de qualidade ruim. Não conseguem trabalho. Sem dinheiro, sem estímulo para o estudo, caem no círculo infernal da decadência pessoal. Passam

\footnotetext{
${ }^{6}$ Sobre o porte de drogas para consumo próprio (artigo 28 da Lei 11.343/2006), pesquisar "Recurso Extraordinário (RE) 635659" que tramita no Supremo Tribunal Federal - STF.
} 
com facilidade da marginalização pessoal para a criminosa. São as presas fáceis do crime, da droga (LIBANIO, 2004, p. 48).

No Brasil, além de se questionar a facilidade com que estes adolescentes adquirem os produtos, pois até aqueles considerados lícitos tem a venda proibida para crianças e adolescentes (Art. 81 do ECA), há que se inconformar com a idade em que, geralmente, iniciam o uso das drogas - em média aos 14 anos (CNJ, 2012).

Figura 27 - Uso de drogas por adolescentes em cumprimento de medidas socioeducativas por região

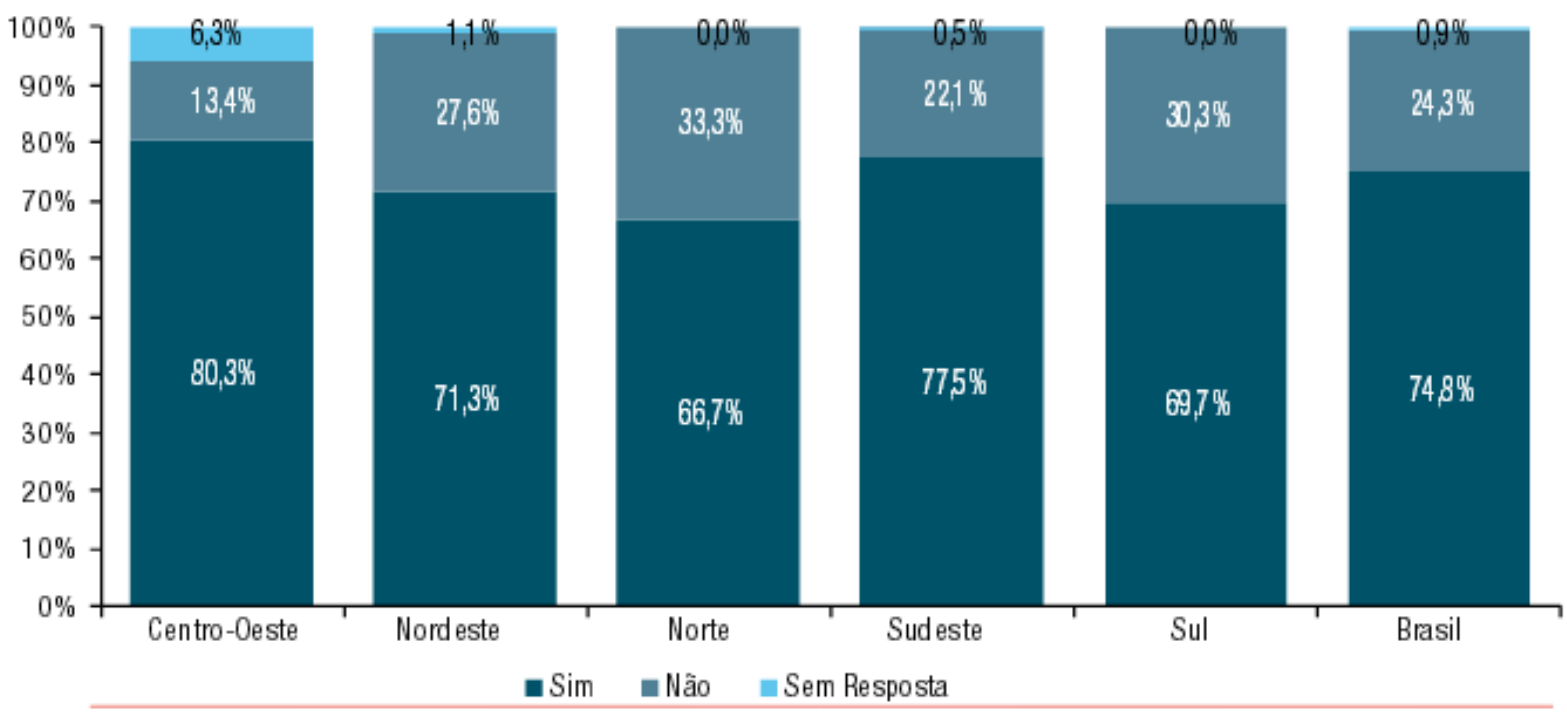

Fonte: CNJ (2012, p. 19). 
Figura 28 - Tipos de drogas utilizadas por adolescentes em cumprimento de medidas socioeducativas por região
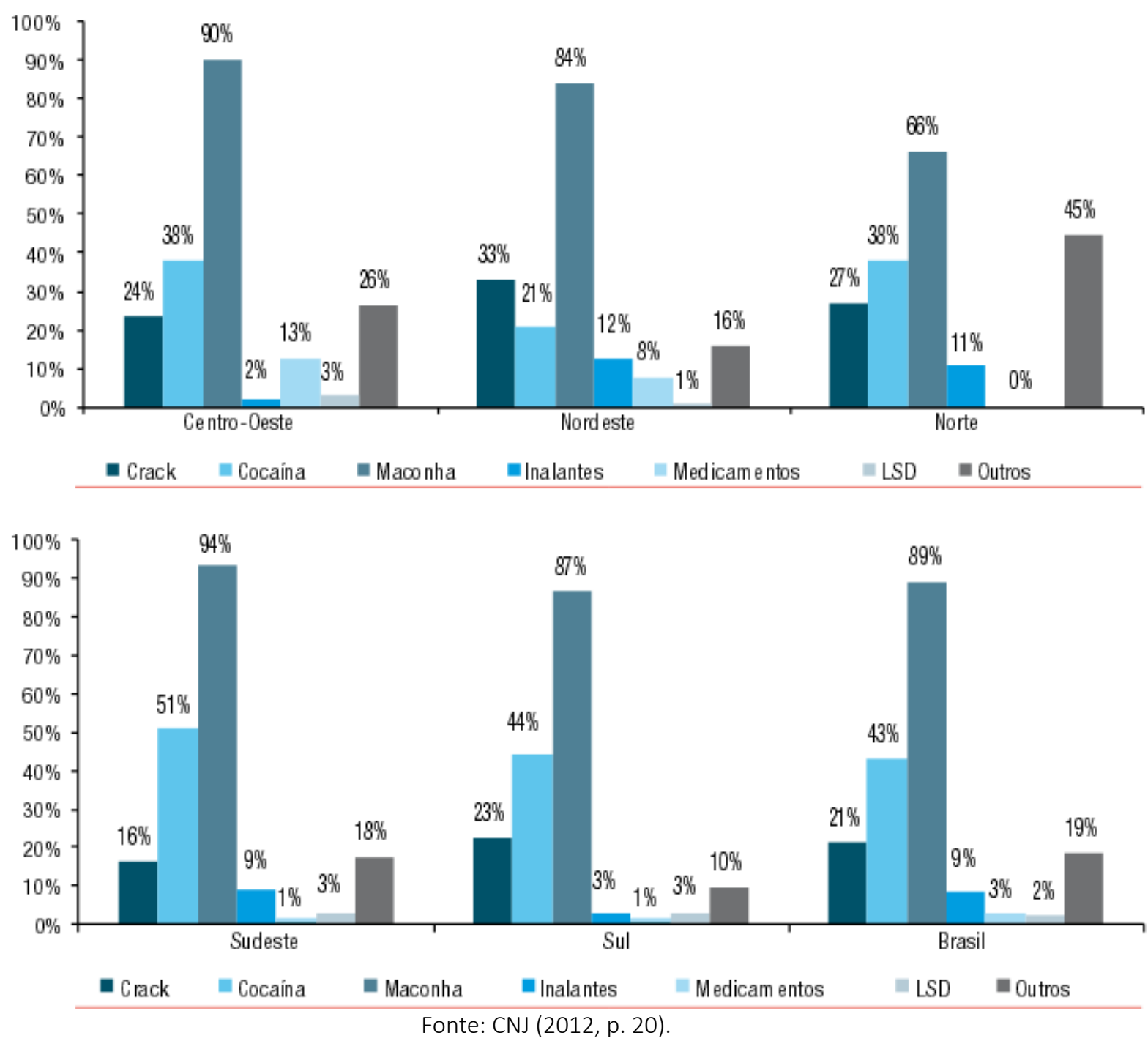

Embora haja diferenças entre o uso e o tráfico de drogas - como doença ou questão de saúde mental e crime, inclusive incorporadas na lei penal, há entre eles, especialmente no caso de adolescente, uma linha muito tênue. Isto porque, para o consumo das drogas o adolescente precisa lançar mão de recursos que na maioria das vezes advém de atos infracionais, ou seja, grande parte deles precisa roubar ou realizar atividades voltadas à organização do tráfico de drogas para suprir suas necessidades de consumo.

Infelizmente, a inserção dos jovens no tráfico de drogas - mais precisamente no 'varejo das drogas' [...], resultante da posição brasileira de corredor de passagem do comércio internacional de drogas e armas voltado para os EUA, a Europa e a Ásia [...] torna nítidas as potencialidades perdidas, os problemas não resolvidos, as demandas esquecidas, os sonhos natimortos de jovens que conjugam procura e 
fuga, reconhecimento social, pertencimento e auto-estima, mesmo que por um período muito curto (embora intenso) e, no mais das vezes, com um fim trágico (MOREIRA; SUCENA; FERNANDES, 2008, p. 152).

Além disto, segundo Moreira, Sucena e Fernandes (2008), o tráfico de drogas seria uma saída ao desemprego ou justificaria a necessidade de ascensão social do jovem, já que com ele há:

[...] descrença por uma possível ascensão social por via do "trabalho legal", pensamento que, em grande parte, relaciona-se às trajetórias de vida de seus responsáveis, parentes e vizinhos em idade adulta. Historias de cidadãos que dedicaram suas vidas ao desempenho de funções pouco valorizadas social e financeiramente [...] e que pouco puderam oferecer a suas famílias em termos de conforto e infra-estrutura (MOREIRA; SUCENA; FERNANDES, 2008, p. 156).

Para os autores, "o mais cruel é que a baixa renda familiar advinda de tais atividades, que não pode ser apontada como causa direta da inserção dos jovens em atividades ilícitas e criminalizadas, atinge efetivamente as perspectivas de futuro" (MOREIRA; SUCENA; FERNANDES, 2008, p. 156), ou seja, quanto menos acesso das famílias aos "equipamentos e serviços públicos resolutivos, mais drasticamente reduz-se a possibilidade de investimentos em saúde, lazer, educação e formação profissional de qualidade para seus componentes mais jovens" (MOREIRA; SUCENA; FERNANDES, 2008, p. 156).

Filho (2008, p. 171), em estudo sobre o tráfico de drogas e juventude pobre no Rio de Janeiro, revela que "entre a juventude, a busca por inclusão econômica é mesmo posterior ou subordinada ao rol de escolhas e objetivos sociais". Segundo o autor, a autorrepresentação e as formas de inclusão disponíveis "são objeto de dinâmicas classificatórias que devem ser compreendidas como mecanismos que informam os investimentos familiares e individuais de inclusão" (FILHO, 2008, p. 171), revelando a importância do consumo na construção das identidades e como facilitador do processo inclusivo.

A ideia de atribuir exclusivamente à fome e à miséria a causa do envolvimento desses jovens com a criminalidade mascara um outro efeito perverso da lógica da chamada economia de mercado, aliada à massificação da mídia: os critérios de pertencimento passam a ser pautados pelo o que se consome (FILHO, 2008, p. 181).

Durante o estudo, Filho (2009, p. 181) entrevistou moradores que, ao serem consultados sobre os jovens e o tráfico de drogas, foram "unânimes em salientar que hoje os jovens entram no tráfico para poder comprar roupas e coisas de marca", diferente do que se via antigamente - a criminalidade era 'justificada' pela pobreza, falta de alimentos e, nesse sentido, identifica um dilema geracional, pois para os mais velhos que participaram de sua entrevista, 
roupas e coisas de marca não justificam 'seguir essa vida', diferente de situações cujas tristes experiências pessoas talvez justificassem.

Outra questão colocada é a complexidade do mercado, já que não se trata apenas de consumir e sim do que se consome, quais são as marcas e os objetos direcionados pela mídia, junto ao mercado, para os jovens, estratificados por classe (e se estratifica dentro das classes - a pobreza, por exemplo, é estratificada) de acordo com sua capacidade de consumir. Para Filho (2008), as opções de consumo não afetam o jovem somente no convite à criminalidade; outras decisões pessoais, como frequentar ou não a igreja também sofre sua influência, uma vez que implicam questões estéticas.

Neste sentido, Moreira, Sucena e Fernandes (2008, p. 160) admitem que, diante da realidade social dos jovens, restam basicamente duas escolhas: a primeira reside em ser um trabalhador pouco qualificado e, em razão disso, com baixíssima remuneração; a segunda, seria integrar a vida do tráfico, "que apesar de arriscada e 'sinistra', irá garantir-Ihe ganhos bem mais elevados e, consequentemente, a satisfação de um número maior de necessidades, em especial as ligadas à aquisição de bens de consumo".

Pouco estudo, múltiplas reprovações, defasagem educacional, histórico de trabalho infantil, cursos profissionalizantes que não surtiram efeito, baixa remuneração, exclusão de direitos trabalhistas, uma sequência de negativas afetando a autoestima dos jovens, o desleixo do poder público. Tais aspectos retratam a situação pessoal e social problemática que os jovens enfrentam, pois reduzem substancialmente suas expectativas de vida e abrem caminho para que a inserção no tráfico de drogas apareça como instância mediadora de seus sonhos e potenciais [...] (MOREIRA; SUCENA; FERNANDES, 2008, p. 160).

Finalmente, resta evidenciar que a importância do debate sobre o uso de substâncias psicoativas e o tráfico de drogas revela-se fundamental no trato do ato infracional praticado por adolescentes, haja visto que se manifestam como pilares sustentáculos de grande parcela das ações praticadas. Muitos jovens justificam que fazer parte do tráfico é fundamental na manutenção da família e/ou no suprimento das necessidades básicas de sobrevivência, enquanto outros justificam que o roubo, o furto ou outras atividades ilícitas foram praticadas para o sustento do vício, pagamento de contas a traficantes ou até mesmo a mando destes, além, é claro, da curiosidade de experimentação que pode levar ao vício, conservação de relações de amizade e pertencimento a um grupo. 


\section{CONSIDERAÇÕES FINAIS}

Em 2017 o Estatuto da Criança e do Adolescente completa 27 anos. Para se refletir ou analisar um trabalho prestado às crianças e adolescentes no Brasil, é necessário se pensar em sua condição histórica e nas múltiplas determinações que incidem na construção desta, principalmente no que se refere ao trabalho junto ao adolescente autor de ato infracional, pois a análise das políticas de atendimento voltadas para as crianças e os adolescentes, permite identificar as diversas concepções de infância e de adolescência que historicamente se mostram dominantes na sociedade brasileira.

A conjuntura que se desenha em torno da violência sofrida ou praticada por adolescentes e jovens é a da manutenção do ideário dominante, numa lógica perversa que tornam invisíveis os que são vítimas e na exceção dos direitos daqueles que são autores, ficando a adolescência e a juventude aquém do exercício dos direitos sociais, revelando que a trajetória das políticas de infância e juventude no Brasil expressa a negação, por parte da sociedade e do Estado, em romper com os paradigmas do passado, comprometendo a efetividade das políticas existentes.

Têm-se um Estado opressor com as crianças e os adolescentes, os mesmos que, em direito e não de fato, têm absoluta prioridade na formulação de políticas e na destinação dos recursos públicos e à juventude, tida como potencialmente violenta, restam os debates de redução da maioridade penal e o endurecimento das penas, ficando evidente, portanto, a necessidade de reformulação das práticas atuais, superando os hábitos do passado, para que seja viabilizado e ampliado o acesso dos cidadãos aos direitos conquistados. Para isso, é necessário que as ações desenvolvidas se oponham às que negam a garantia de direitos.

Vive-se tempos em que o avanço do capitalismo ganha o atributo "ultraliberal" e as mudanças na lógica do capital, marcadas pelo neodesenvolvimentismo desviam as riquezas públicas para os interesses privados, numa afirmação de um Estado de exceção, que flexibiliza as leis sociais, precariza a vida cotidiana da maior parcela da população e massacra numa velocidade acelerada os direitos conquistados, onde estão também os direitos das crianças e dos adolescentes.

Como consequência, têm-se o agravamento da situação de vulnerabilidade social das famílias, empurradas para áreas que não interessam para o mercado imobiliário, onde há pouco ou não há investimentos públicos em saúde, educação, transporte, lazer e cultura e a segurança pública perdeu (por inércia) lugar para o tráfico de drogas - e nem se tratou aqui da exploração 
sexual de crianças e adolescentes. Os locais nobres são "higienizados", são cartões-postais, enquanto que os demais, são lembrados apenas no período eleitoral.

A infância e a adolescência estão fora da lista de interesses do capital, para eles nada, para o capital tudo e este discurso é fortalecido com apoio da mídia (os veículos de comunicação pertencem àqueles que possuem capital), quando tão somente os retrata como problemáticos e delinquentes, dignos de medidas severas para a proteção da sociedade próprias dos aparatos repressores do Estado - fazendo esquecer que, na verdade, são eles próprios os sujeitos merecedores de proteção, realizada pelas políticas sociais.

Manifestam-se também a sociedade violenta, que não consegue sozinha resolver seus conflitos e volta-se para um movimento de judicialização da vida e das relações, um poder público omisso e indiferente às questões da adolescência e da juventude, principalmente a pobre, num tensionamento cada vez mais intenso da vida cotidiana, cujo aprofundamento das desigualdades sociais revela o acatamento à continuidade da impunidade e promove cada vez mais injustiças, isso sem contar as mazelas explicitadas pela ausência de estatísticas ou deficiência no tratamento dos dados de atos infracionais cometidos por adolescentes em todo o país.

É evidente que, embora o perfil socioeconômico do adolescente em conflito com a lei aponte para situações de pobreza, famílias multiproblemáticas, risco e vulnerabilidade social, sabe-se que nas classes sociais mais altas ou entre pessoas de status social mais elevado também há a ocorrência de crimes - em todas as faixas etárias. Exemplo disto são os famosos "crimes de colarinho branco", aqueles cometidos por pessoas de alta posição ou status social, especialmente no uso de suas ocupações, como a corrupção, as fraudes contra o sistema financeiro, penitenciário, a ordem econômica, lavagem de dinheiro, subornos, uso de informações privilegiadas, tráfico de influência, estelionato, peculato, assédio moral e sexual.

Além disso, a subnotificação de atos infracionais cometidos por adolescentes das classes médias e altas estão relacionados aos mecanismos de resolução aos quais estes têm acesso, que incluem desde a contratação de advogados até praticas escusas, como a corrupção de policiais e o tráfico de influências. Para confirmação desta desigualdade de tratamento, basta observar as manchetes da mídia local. Quando um adolescente de classe baixa comete ato infracional, a televisão o apresenta com tarja preta nos olhos, de costas, expõe sua família e as iniciais do seu nome. Apanha da população e vai para a delegacia depois de toda a exibição, agressão e humilhação da família.

Contraditoriamente, quando um adolescente de classe mais alta comete ato 
infracional, nada ou quase nada é veiculado na mídia. Age-se rápido para abafar ou esconder o caso e, sabe-se apenas o informal a partir de alguém que presenciou o fato, filmou via celular e espalhou em redes sociais, ou atendeu no hospital em caso de ferimentos etc. Este não chega à delegacia e seu "desvio" é tratado internamente entre as famílias, com o aval do poder público, cuja gestão, via de regra, está a cargo de pessoas conhecidas destas mesmas famílias.

Diante desta realidade, implementar as políticas para a infância, a adolescência e a juventude (porque uma reflete seus ganhos e perdas sobre a outra) no Brasil e, principalmente, garantir os direitos de cidadania configura-se um grande desafio a ser enfrentado. Para que isso ocorra, é necessária iniciativa estatal e social na perspectiva de desenvolver ações de forma articulada entre os diversos setores, considerando o indivíduo na sua totalidade. Além disso, é preciso desenvolver e dar continuidade a programas e ações que visem prevenir a exposição dos cidadãos a situações de risco e vulnerabilidade social.

\section{REFERÊNCIAS}

ABRAMO, Helena Wendel; BRANCO, Pedro Paulo Martoni. (Orgs.). Retratos da juventude brasileira: análises de uma pesquisa nacional. São Paulo: Fundação Perseu Abramo, 2005.

BASTOS, Paulo Roberto da Silva. Criminalidade feminina: estudo do perfil da população carcerária feminina da Penitenciária Professor Ariosvaldo de Campos Pires - Juiz de Fora (MG). 2009. Âmbito Jurídico. Disponível em: <http://www.ambitojuridico.com.br/site/index.php?n_link=revista_artigos_leitura\&artigo_id=8444>. Acesso em: 03 ago. 2011.

BRASIL. Código Penal. Decreto-lei n. 2.848 de 7 de dezembro de 1940. Dispõe sobre a aplicação da lei penal. Coleção Biblioteca jurídica. Edição atualizada em 1 de janeiro de 2011.

Constituição da República Federativa do Brasil: Texto constitucional promulgado em 5 de outubro de 1988, com as alterações determinadas pelas Emendas Constitucionais de Revisão no 1 a 6/94, pelas Emendas Constitucionais no 1/92 a 90/2015 e pelo Decreto Legislativo no 186/2008. Brasília/DF, 2015.

Estatuto da Criança e do Adolescente. Lei 8.069, de 13 de julho de 1990.

Estatuto da Juventude. Lei no 12.852, de 5 de agosto de 2013.

Ministério da Justiça. Secretaria Nacional de Justiça. Departamento Penitenciário Nacional. Levantamento nacional de informação penitenciária - Infopen Mulheres. Brasília: Ministério da Justiça, 2014.

Ministério da Saúde. Secretaria de Atenção à Saúde. Área de Saúde do Adolescente e do Jovem. Marco legal: saúde, um direito de adolescentes / Ministério da Saúde, Secretaria de Atenção à Saúde, Área de Saúde do Adolescente e do Jovem. - Brasília: Editora do Ministério da Saúde, 2007.

Secretaria-Geral. Índice de vulnerabilidade juvenil à violência e desigualdade racial 2014. Secretaria Nacional de Juventude, Ministério da Justiça e Fórum Brasileiro de Segurança Pública. Brasília: Presidência da República, 2015. - Série Juventude Viva. 
CERQUEIRA, Daniel. Trajetórias individuais, criminalidade e o papel da educação. Instituto de Pesquisa Econômica Aplicada - Ipea. Boletim de análise político-institucional, n.9, jan-jun 2016.

CONSELHO NACIONAL DE JUSTIÇA. Panorama nacional: a execução das medidas socioeducativas de internação. Programa Justiça ao Jovem. Brasília: CNJ, 2012.

CORREA, Sílvio Marcus de Souza. Brasil: uma sociedade de jovens? In.: BRASIL, Ministério da Saúde. Fundação Oswaldo Cruz. Um olhar sobre o jovem no Brasil. Brasília: Editora do Ministério da Saúde, 2008.

COSTA, Maria Clélia Lustosa. Arranjo familiar e vulnerabilidade na região metropolitana de Fortaleza. In.: COSTA, M.C.L.; DANTAS, E.W.C. (Orgs.). Vulnerabilidade socioambiental na região metropolitana de Fortaleza. Fortaleza: Edições UFC, 2009. - Coleção Estudos Geográficos, 4.

DINIZ, Alexandre Magno Alves. Fluxos migratórios e formação da rede urbana de Roraima. Geografia. p. 269-287. Rio Claro, v.33, n.2, 2008.

FILHO, Dario de Souza e Silva. Tráfico de drogas e juventude pobre no Rio de Janeiro: diferenciação de status e fatores intervenientes: o caso da favela de Acari. In.: BRASIL, Ministério da Saúde. Fundação Oswaldo Cruz. Um olhar sobre o jovem no Brasil. Brasília: Editora do Ministério da Saúde, 2008.

FOLHA DE BOA VISTA. Cresce número de crimes praticados por adolescentes. Boa Vista/RR, 27 de junho de 2013 - edição impressa.

FREITAS, Maria Virgínia de (Org.) Juventude e adolescência no Brasil: referências conceituais. São Paulo: Ação Educativa, 2005.

FURTADO, Celso. Reflexões sobre a crise brasileira. In.: ARBIX, G.; ZILBOVICIUS, M.; ABRAMOVAY, R. (Orgs.). Razões e ficções do desenvolvimento. São Paulo: UNESP/Edusp, 2001.

IBGE. Censo Demográfico 2010. Disponível em: <http://www.censo2010.ibge.gov.br/>. Acesso em: 30 ago. 2016.

LIBANIO, João Batista. Jovens em tempo de modernidade: considerações socioculturais e pastorais. São Paulo: Edições Loyola, 2004.

LIMA, Elvira Souza. Como a criança pequena se desenvolve. São Paulo: Sobradinho 107, 2001.

MOREIRA, Marcelo Rasga; SUCENA, Luiz Fernando Mazzei; FERNANDES, Fernando Manoel Bessa. Juventude e tráfico de drogas no Rio de Janeiro. In.: BRASIL, Ministério da Saúde. Fundação Oswaldo Cruz. Um olhar sobre o jovem no Brasil. Brasília: Editora do Ministério da Saúde, 2008.

MURRAY, Isabel. Droga é motivo de $60 \%$ das prisões. 2001. Disponível em: <www.bbc.com/portuguese/noticias/011115_prisaodrogas.shtml >. Acesso em: 28 ago. 2011.

PIRES, Susana; MATOS, Ana; CERQUEIRA, Margarida; FIGUEIREDO, Daniela; SOUSA, Liliana. Retratos da vida das famílias multiproblemáticas. Serviço Social \& Sociedade, no 80, ano XXV. São Paulo: Cortez, 2004. 
PREFEITURA DE BOA VISTA - RR. Mapa cartográfico da cidade - junho 2016. Disponível em: <http://www.boavista.rr.gov.br/ArquivosDinamicos/BASE_GERAL_2016.pdf>. Acesso em: 30 set. 2016.

PREFEITURA MUNICIPAL DE BOA VISTA. Projeto Crescer. Disponível em: <http://www.boavista.rr.gov.br/canal-do-cidadao-projetos/projeto-crescer>. Acesso em: 22 nov. 2016.

POCHMAN, Marcio. Juventude em busca de novos caminhos no Brasil. In.: NOVAES, R.; VANNUCHI, P. (Orgs.). Juventude e sociedade: trabalho, educação, cultura e participação. São Paulo: Fundação Perseu Abramo, 2004.

SECRETARIA de Estado do Planejamento e Desenvolvimento de Roraima - SEPLAN. Roraima: Indicadores Gerais - 2012. Elaboração: DIES. 1a edição. Boa Vista - RR, 2014. 72 pag.

SILVEIRA, Stela Aparecida Damas da. Vulnerabilidade social dos jovens do município de Boa Vista - RR: índice de desenvolvimento juvenil (IDJ) como parâmetro de análise. 95 f. Dissertação (Mestrado em Economia). Universidade Federal do Rio Grande do Sul. Porto Alegre/RS, 2009.

WAISELFISZ, Julio Jacobo. Relatório do Desenvolvimento Juvenil 2007. Rede de Informação Tecnológica Latino-Americana, RITLA. Instituto Sangari e Ministério da Ciência e Tecnologia (MCT), 2007.

YAZBEK, Maria Carmelita. Pobreza e exclusão social: expressões da questão social no Brasil. In.: Temporalis no 3. Brasília: ABEPSS, Gráfica Odisséia, 2004.

Trabalho enviado em 13 de julho de 2017.

Aceito em 11 de novembro de 2017. 